\title{
ONE STEP FORWARD, TWO STEPS BACK: THE COURT AND THE SCOPE OF BOARD DISCRETION IN \\ SURE-TAN, INC. V. NLRB
}

JOAQUIN MÉNDEZ, JR.†

Lay me on an anvil, $O$ God.

Beat me and hammer me into a crowbar.

Let me pry loose old walls.

Let me lift and loosen old foundations.

—Carl Sandburg, Prayers of Steel

The Supreme Court's decision in Sure-Tan, Inc. v. $N L R B^{1}$ highlights some of the fundamental problems in labor law: the inadequacy of traditional National Labor Relations Board (NLRB or Board) remedies for employees discharged in violation of section $8(a)(3)$ of the $\mathrm{Na}$ tional Labor Relations Act (NLRA or Act), ${ }^{2}$ the unsettled scope of judicial review of Board orders, and the pervasive judicial incorporation of pre-NLRA values and assumptions into the Act. In Sure-Tan, these failings produced a "remedy" for an employer's unfair labor practice that, in effect, legitimated the employer's unlawful conduct. The SureTan decision, in contravention of recognized principles of administrative law, improperly and substantially narrows the Board's congressionally mandated discretionary authority to redress violations of section 8(a)(3). ${ }^{3}$ Furthermore, the Sure-Tan Court placed undue stress on notions of private rights and contract law while ignoring the NLRA's

$\dagger$ A.B. 1980, Princeton University; M.A. 1983, Rutgers University (New Brunswick); J.D. Candidate 1986, University of Pennsylvania.

1104 S. Ct. 2803 (1984).

2 Section 8(a)(3) of the National Labor Relations (Wagner) Act declares, in relevant part, that "[i]t shall be an unfair labor practice for an employer . . . by discrimination in regard to hire or tenure of employment or any term or condition of employment to encourage or discourage membership in any labor organization . . ." 29 U.S.C. $\S 158(a)(3)(1982)$.

s Section 10(c) of the NLRA sketches the Board's power to fashion remedies for violations of the Act. In relevant part, the provision states that if the Board finds that a person has engaged in or is engaging in any unfair labor practice, "the Board shall [enter] an order requiring such person to cease and desist from such unfair labor practice, and to take such affirmative action including reinstatement of employees with or without back pay, as will effectuate the policies of this Act." 29 U.S.C. $\S 160$ (c) (1982). 
primary goals, the special competence of the NLRB, and the particular facts of the Sure-Tan case-facts that required a remedy specially tailored to deterring unlawful behavior and vindicating public rights.

Part I of this Comment outlines the principal case and the holdings in the various proceedings. Part II argues that the Court's rejection of the remedy accepted by the Board defies established principles of agency authority and judicial deference to that authority. The SureTan result is inconsistent with the Court's own precedent and usurps the power delegated to the agency under the NLRA. Part III distills the private-law and contract-law values that distorted the Court's interpretation of the Act. These values, substituted for the congressionally defined focus on public rights, rendered the NLRA contentless as applied in Sure-Tan. Part IV of this Comment advocates a revitalization of the public interest in molding effective remedies for unlawful discharges and offers suggestions for obtaining this result.

\section{The Sure-Tan Litigation}

The labor dispute in Sure-Tan developed out of an organizing drive at a leather processing shop. Eight of the shop's eleven employees signed cards authorizing the local chapter of the Amalgamated Meatcutters and Butcher Workmen of North America to act as their collective bargaining representative, and, in a subsequently conducted election, the employees voted in the union."

An hour or two after the election, the company's president, John Surak, upbraided a group of employees, demanding an explanation-"Union why?"- and cursing - "Mexican son of a bitch"; he then asked the employees if they had valid immigration papers, and several replied that they did not. ${ }^{5}$ Surak filed objections to the election, based on the allegation that six of the eligible voters were undocumented aliens. $^{6}$

The Board notified the employer that its objections were overruled and that the union would be certified. Surak then wrote to the Immigration and Naturalization Service (INS) and asked the agency to check into the immigration status of a number of the firm's employees.

- See Sure-Tan, 104 S. Ct. at 2806.

- See NLRB v. Sure-Tan, Inc., 672 F.2d 592, 596 (7th Cir. 1982), affd in part and rev'd in part, 104 S. Ct. 2803 (1984). Mr. Surak's feelings toward the union were known well before the election: "[T]he ALJ noted as background evidence of SureTan's anti-union animus another incident [two months prior to the election] in which ... Surak told [an employee] that he was 'stupid' and that '[he] and the union [were] motherfucker son of a bitches." "Id. at 596 n.3.

${ }^{\circ}$ See Sure-Tan, 104 S. Ct. at 2806. 
Responding to Surak's request, INS agents investigated the status of all of Surak's Spanish-speaking employees. Five employees, discovered to be in the United States illegally, were arrested. ${ }^{7}$ Later that day, the five accepted INS grants of voluntary departure ${ }^{8}$ and boarded a bus bound for the Mexican border. ${ }^{8}$

Shortly after the INS investigation, the Board's Acting Regional Director issued complaints against Sure-Tan alleging that various unfair labor practices had been committed. ${ }^{10}$ The Administrative Law Judge (ALJ) and the Board agreed that the employer's action was unlawful but disagreed as to the appropriate remedy; the ALJ recommended that a minimum of four weeks backpay be awarded, while the Board opted for the traditional remedy of reinstatement with backpay. ${ }^{11}$ The employer appealed to the Court of Appeals for the Seventh Circuit, which, in NLRB v. Sure-Tan, Inc., ${ }^{12}$ affirmed the Board's decision but modified its remedial order in several respects-most significantly by urging the Board to award a minimum of six months' backpay. ${ }^{13}$ The Supreme Court reviewed two issues: first, whether reporting undocumented aliens to the INS in retaliation for union activity can constitute an unfair labor practice; and second, whether the remedial order, as modified by the court of appeals, was valid. ${ }^{\mathbf{1 4}}$

7 See id. Surak's letter to the INS is reprinted in NLRB v. Sure-Tan, Inc., 672 F.2d 592, 599 (1982), affd in part and rev'd in part, 104 S. Ct. 2803 (1984).

${ }^{8}$ The five workers were not deported, as Justice Powell mistakenly asserts. See Sure-Tan, 104 S. Ct. at 2820 (Powell, J., concurring in part and dissenting in part). Deportees are generally not allowed to re-enter the United States for five years following deportation, see 8 U.S.C. $§ 1182($ a)(17) (1982), while persons accepting voluntary departure are exempt from the five-year exclusion, see The IMMIGRATION Project of the National Lawyer's Guild, Immigration Law and Defense Manual $\S \S 7.28(c)(1), 8.7$ (2d ed. 1985).

- See Sure-Tan, 104 S. Ct. at 2806-07.

10 See id. at 2807.

11 See Sure-Tan, Inc., 234 N.L.R.B. 1187, 1187-88 (1978) (Board's decision and order), enforced as modified, 672 F.2d 592 (1982), aff'd in part and rev'd in part, 104 S. Ct. 2803 (1984); id. at 1192 app. (ALJ decision). The ALJ, finding no Board precedent for a backpay award where the former employees are not available for work due to illegal alien status, did not include a backpay award in his order, but rather suggested, in his conclusions of law, that the Board itself devise such an order. See id. The Board's decision and order fails to address the ALJ's recommendation; it simply notes the ALJ's failure to include a backpay award in his order. See id. at 1187. The Board found that there was an insufficient factual basis for concluding that the former employees had not returned to the United States and were therefore unavailable for work. The Board accordingly determined that the ALJ erred in not granting reinstatement with backpay. See id. (1984).

12672 F.2d 592 (7th Cir. 1982), aff d in part and rev'd in part, 104 S. Ct. 2803

1s See id. at 606.

14 See Sure-Tan, 104 S. Ct. at 2806. 


\section{A. The Employer's Conduct Violated the NLRA}

Before addressing the legality of Surak's retaliatory reporting, the Court agreed with the tribunals below that undocumented aliens are "employees" for purposes of the NLRA. ${ }^{15}$ Undocumented aliens, it

15 See id. at 2808-10. Seven justices joined parts II and III of Justice O'Connor's opinion, which held that undocumented workers are NLRA employees and that retaliatory reporting to the INS is an unfair labor practice. See id. at 2808-12 (O'Connor, J., joined by Burger, C.J., and White, J.); id. at 2816-17 (Brennan, J., concurring in part and dissenting in part, joined by Marshall, Blackmun, and Stevens, JJ.); cf. Hasa Chem., Inc., 235 N.L.R.B. 903 (1978) (holding that deterring union activity by threatening deportation violates the NLRA); Sure-Tan, Inc. and Surak Leather Co., 231 N.L.R.B. 138 (1977) (requiring that undocumented aliens be included in collective bargaining units), enforced, 583 F.2d 355 (7th Cir. 1978). that

Section 2(3) of the NLRA defines the term "employee," stating, in relevant part,

[t]he term "employee" shall include any employee . . . but shall not include any individual employed as an agricultural laborer, or in the domestic service of any family or person at his home, or any individual employed by his parent or spouse, or any individual having the status of an independent contractor, or any individual employed as a supervisor, or any individual employed by ... any other person who is not an employer as herein defined.

29 U.S.C. § 152(3) (1982).

The Court arrived at the conclusion that undocumented aliens were "employees" under the NLRA by giving "considerable deference" to the Board's determination of the issue. See Sure-Tan, 104 S. Ct. at 2809. It reaffirmed that the Board was the agency created by Congress to administer the Act, that the responsibility for giving substance to the term "employee" belonged primarily to the Board, and that the Court would, therefore, uphold any "reasonably defensible" construction of that term by the Board. Id. In support of its deference toward the Board in this respect, the Court cited NLRB v. Hearst Publications, 322 U.S. 111 (1944). See Sure-Tan, 104 S. Ct. at 2809. In Hearst the Court announced that

where the question is one of specific application of a broad statutory term in a proceeding in which the agency administering the statute must determine it initially, the reviewing court's function is limited. ... [T] Board's determination that specified persons are "employees" under this Act is to be accepted if it has "warrant in the record" and "a reasonable basis in law."

Id. at 131 .

The Court's invocation of Hearst is of interest for two reasons. First, it allows a comparison between the Court's deferential standard for reviewing the Board's definition of an "employee" and its non-deferential standard for reviewing the Board's assessment of appropriate remedies. See infra notes 73-82 and accompanying text. Second, it highlights the Court's double standard in another, more fundamental respect. In Hearst the Court sustained the propriety of the Board's determination that newsboys were "employees" under the Act. Shunning rigid formalism, the Court asserted that-due to the broad language in which the Act's definitions are cast-the Act's applicability must "be determined broadly, in doubtful situations, by underlying economic facts rather than technically and exclusively by previously established legal classifications." Hearst, 322 U.S. at 129. The term "employee," the Court continued, "like other provisions, must be understood with reference to the purpose of the Act and the facts involved in the economic relationship. 'Where all the conditions of the relation require protection, protection ought to be given." Id. (quoting Lehigh Valley Coal Co. 
noted, are not included in the few groups of workers expressly excluded from the Act's protection. ${ }^{16}$ The exclusion of undocumented aliens, the Court added, would create a subclass of workers ${ }^{17}$ with no stake in collective bargaining, an effect that would erode the unity of all employees and impede effective bargaining. ${ }^{18}$

Extending the NLRA's coverage to include undocumented aliens required the Court to examine a potential conflict between such an extension and the policies of the Immigration and Nationality Act (INA). ${ }^{19}$ In concluding that undocumented workers come within the scope of the NLRA, the Court noted that an employment relationship involving an undocumented alien is not illegal under the INA. ${ }^{20}$ The

v. Yensavage, 218 F. 547, 552 (2d Cir. 1914)) (emphasis added) (footnotes omitted). In its construction of the Act's provision empowering the Board to issue remedies that will "effectuate the policies" of the Act, the Sure-Tan Court departed significantly from the Hearst Court's focus on the central policy objectives of the Act and on social realities as determined by the Board. The Sure-Tan Court did not defer to the Board, but rather performed precisely the sort of formalistic interpretation of the Act that was rejected in Hearst.

18 See Sure-Tan, 104 S. Ct. at 2809; see also supra note 15 (quoting section 2(3) of the NLRA, which excludes, for example, agricultural laborers and domestic workers from coverage under the Act).

${ }_{17}$ See Sure-Tan, 104 S. Ct. at 2809. The Court has recognized the problem of undocumented aliens accepting jobs "on substandard terms as to wages and working conditions." De Canas v. Bica, 424 U.S. 351, 356-57 (1976); see also United States v. Brignoni-Ponce, 422 U.S. 873, 879 (1975) (Undocumented aliens are especially susceptible to discrimination and exploitation by employers.); $c f$. Plyler v. Doe, 457 U.S. 202, 218-19 (1982) (discussing "the specter of a permanent caste of undocumented resident aliens encouraged by some to remain here as a source of cheap labor, but nevertheless denied the benefits that our society makes available to citizens and lawful residents") (footnote omitted). Substandard working conditions persist because undocumented immigrant workers are deterred from taking action-either through union activities or by reporting substandard conditions to appropriate government agencies-by the constant threat of apprehension by immigration authorities.

${ }^{18}$ See Sure-Tan, $104 \mathrm{~S}$. Ct. at 2809 . The Court has recognized that Congress considered unified strength on the part of labor a necessity for effective bargaining. See NLRB v. Jones \& Laughlin Steel Corp., 301 U.S. 1, 33 (1937). This unity would be destroyed if there existed, within the ranks of an employer's workforce, a "subclass" of employees, otherwise indistinguishable from their fellow employees, who lacked the right to participate in union activities free of employer intimidation. Coverage under the NLRA and the application of effective remedies for violations of the Act would deter employers from notifying the INS in retaliation for union activities, and thus would remove a major obstacle to the progressive unionization of those sectors of the labor force that employ large numbers of undocumented workers. This, in turn, would result in improved working conditions for all employees and would further the progress of collective bargaining in general. See De Canas v. Bica, 424 U.S. 351, 356-57 (1976) ("IA]cceptance by illegal aliens of jobs on substandard terms as to wages and working conditions can seriously depress wage scales and working conditions of citizens and legally admitted aliens; and employment of illegal aliens under such conditions can diminish the effectiveness of labor unions.").

19 Immigration and Nationality Act, ch. 477, 66 Stat. 163 (1952) (codified as amended in scattered sections of 8 U.S.C.).

${ }^{20}$ See Sure-Tan, 104 S. Ct. at 1809-10. Adding an ominous note to its opinion, 
Court found that extending the NLRA's coverage to undocumented aliens was, in fact, compatible with such INA goals as the preservation of jobs for American workers. ${ }^{21}$ Including undocumented aliens within the scope of the NLRA, reasoned the Court, lessened the incentive for employers to hire undocumented aliens and thus was consistent with INA policy. ${ }^{22}$

Having found that the five undocumented alien workers were entitled to the protection of the Act, the Court turned to "the more difficult issue," whether the retaliatory reporting was a section $8(a)(3)$ unfair labor practice. ${ }^{23}$ Because the Sure-Tan employees were not discharged in the traditional sense, the Court adopted and applied an expansive approach towards evaluating employer behavior:

The Board, with the approval of lower courts, has long held that an employer [commits a section $8(a)(3)$ unfair labor practice] not only when, for the purpose of discouraging

the Court included the otherwise superfluous explanation that it had no difficulty reconciling the NLRA to "the immigration laws as presently written." Id. at 2810 (emphasis added). The Court probably intended to signal its awareness of the SimpsonMazzoli bill, S. 529, 98th Cong., 1st Sess. (1984), which was pending in Congress at that time. The bill would have made illegal an employment relationship between a U.S. employer and an undocumented alien. See id. tit. I, pt. A. The Court may have been suggesting that such a law might supercede its finding that including undocumented aliens as "employees" under the NLRA does not conflict with immigration laws.

Although the Simpson-Mazzoli bill was not enacted, a number of states have enacted laws with provisions similar to those contained in the Simpson-Mazzoli bill. See, e.g., CAL. LAB. CodE § 2805(a) (West Supp. 1986) ("No employer shall knowingly employ an alien who is not entitled to lawful residence in the United States if such employment would have an adverse effect on lawful resident workers."); DEL. CODE ANN. tit. $19, \S 705$ (a) (1985) (virtually the same provision). The Court has found such provisions to be constitutional. See De Canas v. Bica, 424 U.S. 351 (1976).

${ }^{21}$ See Sure-Tan, 104 S. Ct. at 2810.

22 See $i d$. Although the difficulty of obtaining precise information regarding undocumented aliens is obviously enormous, one survey of undocumented aliens found that over one-fifth of all respondents received wages below the legal minimum. See Comment, The Right of Undocumented Aliens Against Their Employers, 10 FORDHAM URB. L.J. 683, 685 n.12 (1982) (citing North \& Houstoun, The Characteristics and Role of Illegal Aliens in the U.S. Labor Market: An Exploratory Study (1976), reprinted in Cong. Research Service, 96Th Cong., 1st Sess., Selected Readings ON U.S. Immigration Policy and Law 77, 89 (Comm. Print 1980)). In addition, cases such as Sure-Tan suggest that employers may choose to hire undocumented aliens because of their belief that these workers will be unsupportive of union activities and will be reminded of their civic duty to report undocumented workers only when these workers engage in pro-union activities. See NLRB v. Sure-Tan, 672 F.2d at 601 n.14 ("There seems nothing like a successful union election to concentrate an employer's mind on the color of its workers' visas (if they exist) and on its moral obligations to expel its (once faithful) employees from the country.").

${ }_{23}$ See Sure-Tan, $104 \mathrm{~S}$. Cit. at 2810 . Under section $8(\mathrm{a})(3)$, it is an unfair labor practice for an employer "by discrimination in regard to hire or tenure of employment or condition of employment to encourage or discourage membership in any labor organization." 29 U.S.C. $§ 158(a)(3)$ (1982). 
union activity, it directly dismisses an employee, but also when it purposefully creates working conditions so intolerable that the employee has no option but to resign-a socalled "constructive discharge."24

Under this test, the employer's actions must be animated by a desire to thwart unionism and must be the actual cause of the employee's job loss. ${ }^{25}$ With respect to the employer's anti-union animus, the Court agreed with the Seventh Circuit's finding that this requirement had been "flagrantly met." "26 The second element of the section $8(a)(3)$ violation was not, however, so easily established. The Court was required to see through Sure-Tan's seductive veil of formalism: an argument that it was not the employer's communication with the INS but rather the employees' status as undocumented aliens that was the "proximate cause" of the employees' departure from the country. ${ }^{27}$ The Court found Sure-Tan's argument "unavailing"; it adopted the ALJ's conclusion that "but for [Surak's] letter to Immigration, the discriminatees would have continued to work indefinitely." "28 "[T]here can be little doubt," noted the Court, "that Surak foresaw precisely this result when, having known about the employees' illegal status for some months, he notified the INS only after the Union's electoral victory was assured."29

\section{B. A Violation of the Act in Search of a Remedy}

The second issue examined by the Sure-Tan Court concerned the propriety of the Board's remedial order, as modified by the court of appeals. The most problematic of the appellate court's modifications, in the Supreme Court's opinion, was what the Court saw as a requirement that the employer provide each of the five discriminatees with six months' backpay as a "minimum amount for purposes of effectuating the policies of the Act."so

24 Sure-Tan, 104 S. Ct. at 2810 (citations omitted).

25 See id. at 2810-11.

${ }^{26} \mathrm{Id}$. at 2810 (quoting NLRB v. Sure-Tan, 672 F.2d at 601).

27 See id. opinion)).

${ }^{28}$ Id. (quoting Sure-Tan, Inc., 234 N.L.R.B. 1187, 1191 app. (1978) (ALJ

20 Id. at $2810-11$.

so NLRB v. Sure-Tan, 672 F.2d at 606. The Supreme Court analyzed the backpay award as though it had been "ordered" by the court of appeals. See Sure-Tan, $104 \mathrm{~S}$. Ct. at 2813. A close reading of the Seventh Circuit opinion reveals, however, that the court did not order such an award, but rather indicated that such an award was appropriate and would be enforced by the court should the Board decide to adopt it. The circuit court referred to the six-month backpay award as one that would be 
It is the Board's general policy to toll backpay awards during any period of time in which the unlawfully discharged employee is not available for work, such as when the employee is not present in the country. ${ }^{31}$ Because the discharged employees would be deemed unavailable for work during any period when they were not legally entitled to be present and to seek employment in the United States, ${ }^{32}$ a conventional backpay order might produce no backpay monies at all. ${ }^{33}$

The six-month backpay award, the court of appeals argued, was permissible and desirable for several reasons. First, the court recognized the need "to vindicate the policy of the Act and to deter similar conduct by other employers in the future." "[T]he rights of both alien and non-alien employees under the Act," declared the court, "are flouted if employers are free to discriminate against alien employees who exercise their right to form and join unions." 35 Second, to deny the former em-

"permitted"; it asserted that "the Board could fix a time which is the minimum. . . . [W]e think that six months is a reasonable assumption," and concluded by "giv[ing] leave to the Board, if it sees fit, to modify [the order] further by setting a minimum period of six months during which backpay will be awarded." NLRB v. Sure-Tan, 672 F.2d at 606 (emphasis added). In short, the Seventh Circuit opinion appears to have been misread by the Supreme Court: the Seventh Circuit approved, but did not require, a backpay award.

In addition to permitting modification of the backpay award, the court of appeals modified the Board's order by requiring the employer to draft the reinstatement offers in Spanish and to ensure verification of their receipt in Mexico. See id. at 606. It required further that the reinstatement offers be held open for four years to allow the five discriminatees time to gain legal reentry into the United States. See id.

The Sure-Tan Court found that the remedial modifications, other than the six months' backpay, were beyond the lower court's "limited authority of judicial review." Sure-Tan, 104 S. Ct. at 2816. The Court did not suggest that such remedies would be improper if they had originally been fashioned by the Board. On the contrary, the Court sought only to preserve "the congressional scheme investing the Board and not the courts with broad powers to fashion remedies that will effectuate national labor policy." "Sure-Tan, 104 S. Ct. at 2816 (quoting NLRB v. Food Store Employees, 417 U.S. 1,10 (1974)).

The court of appeals also modified the Board's original order by requiring that the offers of reinstatement be conditioned on the employees' legal reentry and availability to work in the United States. See NLRB v. Sure-Tan, 672 F.2d at 606. The Board's acquiescence in this portion of the reviewing court's modification was apparently identical to its incorporation of the other changes. However, while the Supreme Court refused to treat the other changes as the Board's own because they were tainted by the appellate court's overextension of its reviewing authority, see infra notes 41-45 and accompanying text, the Court did allow that this one alteration of the Board's order was "fully accepted" by the Board and upheld it. See Sure-Tan, 104 S. Ct. at 2815 n.12.

s1 See, e.g., Gary Aircraft Corp., 210 N.L.R.B. 555, 557 (1974) (finding backpay liability tolled for a period of time during which the discriminatee was on vacation and thus removed from the job market).

${ }^{32}$ See NLRB v. Sure-Tan, 672 F.2d at 606.

ss See id.

s4 Id. at 604 .

ss Id. 
ployees a remedy would produce an unacceptable result: "It would be anomalous to encourage the honest toil of illegal aliens, accepting it with the understanding that these workers had the rights of employees under the Act, but then, when violations occur, to deny them such rights by refusing effective remedies." opted for six months' backpay because it was a "reasonable assumption" that "the discriminatees might reasonably have remained employed [for six months] without apprehension by [the] INS, but for the employer's unfair labor practice," and, after all, "it was [the employer's] discriminatory act which caused these employees to lose their jobs." ${ }^{\text {37 }}$

The Supreme Court rejected the remedy suggested by the court of appeals for two reasons. First, the Court found that the court of appeals had overstepped the limits of its reviewing authority by fashioning its own remedy for the unfair labor practice: "Because the relation of remedy to policy is peculiarly a matter for administrative competence, courts must not enter the allowable area of the Board's discretion ...." "ss Thus, "[t]he proper course for a reviewing court that believes a Board remedy to be inadequate is to remand the case to the Board for further consideration."s9 It appears, however, that the Supreme Court misinterpreted the Court of Appeals decision. The Seventh Circuit did not order the six-month backpay award, but merely suggested that the Board adopt such a remedy. ${ }^{10}$ Thus, the Court was objecting to an exercise of judicial authority that had not actually occurred.

Second, there was, in the Court's opinion, a more fundamental defect in the six-month backpay award that would have remained uncured even if it had been ordered in the first instance by the Board itself. ${ }^{41}$ The Seventh Circuit's order, the Supreme Court declared, "effectively compelled the Board to take action that simply does not lie

so $I d$.

97 Id. at 606.

s8 Sure-Tan, 104 S. Ct. at 2813 (quoting Phelps Dodge Corp. v. NLRB, 313 U.S. 177,194 (1941)).

30 Id. at 2813 n.10 (citation omitted).

10 See supra note 30.

41 The Board "fully acquiesced" in the Seventh Circuit remedy, leading Justice Brennan to argue that the Court should "approach this case as if the Board had developed the remedial order on its own motion," since "no purpose would be served by remanding to the Board." Sure-Tan, $104 \mathrm{~S}$. Ct. at 2817 (Brennan, J., concurring in part and dissenting in part). Justice O'Connor, however, rejected Justice Brennan's suggestion because the Board itself had not "duly considered" the remedy and because there was no evidentiary record on the specific circumstances of the former employees. Id. at 2813 n.9. 
within the Board's own powers."42 The six-month backpay award failed because, as the Court saw it, it was "not sufficiently tailored to the actual, compensable injuries suffered by the discharged employees." "13 The award was incurably defective because it was based on "pure speculation and [did] not comport with the general reparative policies of the NLRA."44 Most provocative was the Court's pronouncement that "it remains a cardinal, albeit frequently unarticulated assumption, that a backpay remedy must be sufficiently tailored to expunge only the actual, and not merely [the] speculative, consequences of the unfair labor practices."45

\section{Board Discretion and Judicial Deference}

The Sure-Tan Gourt's rejection of the six-month backpay award signals a departure from both conventional principles of administrative law and the Court's own long-established precedent. The unfortunate consequence of the Court's approach is an improper and substantial reduction in the Board's congressionally authorized discretion to redress violations of the NLRA.

\section{A. The Board's Discretion to Formulate Remedies}

The enactment of the NLRA marked the adoption of a newly formulated national labor policy, ${ }^{\mathbf{4}}$ a policy that required elaboration, enforcement, and vindication. Congress placed primary responsibility for performing these tasks in the National Labor Relations Board ${ }^{47}$ and granted the Board broad quasi-judicial powers to facilitate the fulfill-

62 Id. at 2813 (emphasis added).

43 Id. at 2814.

44 Id. (footnote omitted). The Court gave its general endorsement to the Board's original order-reinstatement with backpay, see id. - which the court of appeals found would probably yield no backpay award and no reinstatement. See NLRB v. Sure-Tan, 672 F.2d at 606.

45 Id. at 2813-14 (emphasis added to "unarticulated assumption").

16 See National Labor Relations (Wagner) Act \& 1, 29 U.S.C. § 151 (1982) (declaring "it to be the policy of the United States to ... encourag[e] ... collective bargaining and ... protect[ ] the exercise by workers of full freedom of association, self-organization, and designation of representatives of their own choosing, for the purpose of negotiating the terms and conditions of their employment"); $c f$. Klare, Judicial Deradicalization of the Wagner Act and the Origins of Modern Legal Consciousness, 1937-1941, 62 MinN. L. REv. 265, 265 (1978) ("When passed the [NLRA] was perhaps the most radical piece of legislation ever enacted by . . . Congress.") (footnote omitted).

${ }^{47}$ See National Labor Relations (Wagner) Act $\S 10,29$ U.S.C. § 160 (1982) (describing powers vested in the Board to prevent unfair labor practices). It is the General Counsel's Office, however, that enforces the NLRA by acting on complaints of violations. See id. § 3(d), 29 U.S.G. § 153(d) (1982). 
ment of that responsibility. Described in section 10 (c) of the Act, ${ }^{48}$ these powers give the Board great flexibility and discretion ${ }^{49}$ to prevent the commission of unfair labor practices and to rectify the effects of violations already committed. ${ }^{\text {so }}$ As such, it is clear that "Congress regarded the ability of the Board to make and enforce effective decisions a vital feature of the Act." 151 One commentator has argued that the drafters of section 10 (c) intentionally utilized indefinite language in order to ensure a broad and flexible authority for the Board; such language allows the Board to "set the tenor of its own authority by imaginative and specific treatment of the unique circumstances surrounding each unfair practice." ${ }^{\text {(12 }}$ It is also noteworthy that the Act charges the NLRB with an obligation to implement a national labor policy. "When Congress has charged an agency [such as the NLRB] with the duty to make and implement a national policy, it is more likely that Congress intended the agency to have some flexibility, free from judicial intrusion, in interpreting the Congressional grant."

What has been termed "remedial inventiveness" w5 was demonstrated by unfair labor practice proceedings involving J.P. Stevens \& Company. ${ }^{56}$ In one of the J.P. Stevens cases, the Board directed the

48 Id. $\S 10(c), 29$ U.S.C. $\S 160$ (c) (1982); see also supra note 3 (discussing and quoting from section $10(c))$.

10 Although congressional records contain only a meager discussion of the Board's powers under section 10(c), see Note, The Need for Creative Orders Under Section 10(c) of the National Labor Relations Act, 112 U. PA. L. REv. 69, 69 (1963), the following statement suggests the relatively free hand Congress intended the Board to have:

The orders will of course be adapted to the needs of the individual case; they may include such matters as refraining from collective bargaining with a minority group, recognition of the agency chosen by the majority for the purposes of collective bargaining, posting of appropriate bulletins, refraining from bargaining with an organization corrupted by unfair labor practices. The most frequent form of affirmative action required in cases of this type is specifically provided for, i.e., the reinstatement of employees with or without back pay, as the circumstances dictate.

H.R. ReP. No. 1147, 74th Cong., 1st Sess. 24 (1935), quoted in Note, supra, at 69 n.5. Several courts have compared the Board's flexibility with that of a chancellor in equity. See id. at 79; see also id. at $79 \mathrm{n} .97$ (collecting cases).

${ }_{\text {so }}$ See Note, supra note 49, at $73 \mathrm{n} .42$ (discussing legislative history).

52 Id. at 69; cf. J. AtLEson, VAlUes AND Assumptions in AMERICAN LABOR LAw 37-40 (1983) (noting that lack of enforcement of section 7(a) of the National Industrial Recovery Act was one reason/for enactment of the NLRA).

${ }^{62}$ Note, supra note 49 , at 70 .

ss See supra note 46.

s4 Pittsdon Stevedoring Corp. v. Dellaventura, 544 F.2d 35, 49 (2d Cir. 1976) (citations omitted).

ss A. Cox, D. Bok \& R. Gorman, Cases on Labor Law 252 (9th ed. 1981).

os See id. at 252 (discussing a sequence of cases involving J.P. Stevens \& Co. with particular emphasis on the remedies ordered by the Board). 
company to establish a " 'continuing program for the proper education of J.P. Stevens management personnel in the area of the rights of union organizers." "5z In another J.P. Stevens case, the Fifth Circuit, explaining the need for flexibility and adaptation in remedies, recognized that "[r]esourceful and imaginative NLRB orders are essential. The labormanagement relations of industry are varied and complex. Courts of Appeals cannot require the Board to use only round pegs when the holes may be square, triangular, rectangular, or even pentagonal."'s8

The Court's general view that the application of the NLRA should be informed "by underlying economic facts rather than technically and exclusively by previously established legal classifications"50 applies to the fashioning of remedies. Thus, for example, the Board's determination of a reasonable employee response time for a reinstatement offer "will depend essentially on the situation in which an employee finds himself as a result of the discrimination against him."

Creativity and imagination in the fashioning of remedies ${ }^{61}$ is particularly well illustrated by the Supreme Court's decision in NLRB v. Gissel Packing Co. ${ }^{62}$ Gissel represents the high-water mark in the use of extraordinary remedies when traditional remedies are deemed insufficient to erase the particularly severe effects of an unfair labor practice. The Gissel Court held that unfair labor practices relating to a union election could be remedied by a bargaining order and Board certification of a union ${ }^{63}$ based only on the fact that a majority of the company's employees had signed authorization cards. ${ }^{64}$ Thus, where an election was invalidated due to the employer's unfair labor practice, the Court found that the Board's remedy need not be limited to the traditional ordering of a new election. The Court upheld the Board's bargaining order even though a valid election had never been held. ${ }^{65}$ Cases

${ }^{57}$ NLRB v. J.P. Stevens \& Co., 563 F.2d 8, 23 (2d Cir.) (quoting from the Master's report in the case), cert. denied, 434 U.S. 1064 (1978). omitted).

${ }^{58}$ J.P. Stevens \& Co. v. NLRB, 417 F.2d 533, 538 n.10 (5th Cir. 1969) (citations

69 NLRB v. Hearst Publications, 322 U.S. 111, 129 (1943) (citations omitted); see also supra note 15 (discussing Hearst); supra note 49 (quoting legislative history that discusses the formulation of remedies by the Board).

${ }^{60}$ Fredeman's Calcasieu Locks Shipyard, 208 N.L.R.B. 839 (1974); see also NLRB v. Murray Prods., 584 F.2d 934, 940 (9th Cir. 1978) ("[T]he validity of the [reinstatement] offer depends on the situation in which the offeree finds himself as a result of the discrimination against him.").

${ }_{61}$ See J.P. Stevens \& Co. v. NLRB, 417 F.2d 533, 538 n.10 (5th Cir. 1969); Note, supra note 49 , at $70,76$.

62395 U.S. 575 (1969).

63 See id. at 597-98.

64 See id. at 614-15.

${ }^{65}$ See id. 
such as Gissel and those involving J.P. Stevens \& Company demonstrate the NLRB's tradition of designing particularized remedies for cases in which adherence to convention would prove ineffectual.

\section{B. General Principles of Judicial Deference to the Board}

In finding that alien workers were "employees" under the Act, ${ }^{68}$ the Sure-Tan majority seemed to accept the high standard of deference to the Board suggested by Gissel. Giting NLRB v. Hearst Publications, ${ }^{67}$ the Sure-Tan Court noted that the Board's construction of a statutory term (such as "employee" in Hearst and Sure-Tan) is "entitled to considerable deference."

[w] here the question is one of specific application of a broad statutory term in a proceeding in which the agency ... must determine it initially, the reviewing court's function is limited. . . . [T] he Board's determination that specified persons are "employees" under this Act is to be accepted if it has "warrant in the record" and a reasonable basis in law. ${ }^{69}$

The Court further held that a Board determination must be made in light of "underlying economic facts" rather than through technical and exclusive reliance on "previously established legal classifications."

Such a standard is susceptible to interpretation as a recognition either of the Board's broad discretion or of its limited discretion (since the Court is the final judge of reasonableness). ${ }^{71}$ For two reasons the former is the better interpretation. First, the requirement that the Board interpret the Act in light of "underlying economic facts" suggests the wisdom of judicial deference to Board expertise. The labor specialists who constitute the Board are, generally speaking, better equipped to interpret the Act so that it might best serve its broad purposes. Second, the "reasonableness" limitations on the Board's power to interpret statutory terms, like the similar limitations on the Board's power to find facts-a process which also requires the scrutiny of "underlying economic facts"- are no more than reflections of an obvious truth: "[I]f administrative agencies were totally free to find whatever facts they pleased, without regard to the evidence or the reasonableness of infer-

Bo See Sure-Tan, 104 S. Ct. at 2808-09.

67 322 U.S. 111 (1944).

68 Sure-Tan, 104 S. Ct. at 2809.

69 Hearst, 322 U.S. at 131.

70 Id. at 129.

71 For a discussion of cases going both ways, see K. Davis, Administrative LaW Treatise $\S \S$ 29:10-29:12 (2d ed. 1984). 
ences that might be drawn from the evidence, agencies could so alter the operation of statutes or legal rules as to effectively change their meaning." 72

The Sure-Tan Court noted the need for "considerable deference" to statutory interpretations by the Board and thus appeared to accept the "broad discretion" interpretation; the Court refused, however, to extend such deference to the backpay remedy accepted by the Board, holding that the remedy was beyond the Board's discretion. ${ }^{\mathbf{7 3}}$ Arguably, a stronger case exists in favor of judicial deference to the selection of remedies by the Board than exists in favor of deference to statutory interpretation by the Board. Section 10 (c) of the Act explicitly requires the Board "to take such affirmative action including reinstatement of employees with or without back pay, as will effectuate the policies of this Act." It It is well settled that "[w]here . . . a determination has been left to an administrative body, this delegation will be respected and the administrative conclusion left untouched."75 For the same reasons noted in connection with the Board's power of statutory interpretation, the Board's exercise of discretion granted to it by Congress will be restricted only if the order is " unwarranted in law or . . . without justification in fact." "'76

The Supreme Court has only recently reaffirmed this principle of deference to an administrative agency's exercise of statutory power. In Chevron, U.S.A. v. Natural Resources Defense Council, ${ }^{77}$ the Court stated:

We have long recognized that considerable weight should be accorded to an executive department's construction of a statutory scheme it is entrusted to administer, and the principle of deference to administrative interpretations "has been consistently followed by this Court whenever decision as to the meaning or reach of a statute has involved reconciling con-

72 S. Breyer \& R. Stewart, Administrative Law and Regulatory PolICY 202 (2d ed. 1985).

${ }^{73}$ See Sure-Tan, 104 S. Ct. at 2813.

74 National Labor Relations (Wagner) Act $\S 10(c), 29$ U.S.C. $\S 160(c)$ (1982).

75 Gray v. Powell, 314 U.S. 402, 412 (1941); see also American Power Co. v. SEC, 329 U.S. 90, 112 (1946) ("[W]here Congress has entrusted an administrative agency with the responsibility of selecting the means of achieving the statutory policy 'the relation of remedy to policy is peculiarly a matter for administrative competence." ") (quoting Phelps Dodge Corp. v. NLRB, 313 U.S. 177, 194 (1941)); Butz v. Glover Livestock Comm'n, 411 U.S. 182, 185 (1973) (adhering to the American Power standard for judicial review of administrative agency decisions).

${ }^{76}$ Butz v. Glover Livestock Comm'n, 411 U.S. 182, 185-86 (1973) (quoting American Power Co. v. SEC, 392 U.S. 90, 112-13 (1946)) (citations omitted).

77104 S. Ct. 2778 (1984). 
flicting policies, and a full understanding of the force of the statutory policy in the given situation has depended upon more than ordinary knowledge respecting the matters subjected to agency regulations." 78

Chevron suggests that the reason for deferring to the Board's exercise of statutory power is identical to that for deferring to the Board's statutory interpretation. When the expertise of the Board is implicated, particularly when "statutory policy," as in Chevron, or "underlying economic facts," as in Hearst, are involved, a reviewing court should grant "considerable deference" to the Board. As the Court stated in Ford Motor Co. v. NLRB: ${ }^{79}$ ?

[W]e should "recognize without hesitation the primary function and responsibility of the Board," which is that "of applying the general provisions of the Act to the complexities of industrial life . . . and of '[appraising] carefully the interests of both sides of any labor-management controversy in the diverse circumstances of particular cases' from its special understanding of the 'actualities of industrial relations.' "\$8

Thus it appears that the Sure-Tan Court acted improperly in substituting its judgment as to the appropriate remedy; it is the Board, not the courts, that has the explicit power to award backpay. ${ }^{81}$ When the Court deferred to the Board's finding that the undocumented aliens were "employees" for purposes of the Act, the Court, by implication, deferred to the Board's expertise in looking at "underlying economic facts." ${ }^{\text {82 }}$ Given such deference, the Court should not have found that the Board lacked the discretion to fashion the six-month backpay award. The Ford Motor decision suggests that, for the same reasons that courts should defer to an agency's statutory interpretation, they should defer to an agency's statutory power to design remedies.

\section{Principles of Judicial Deference to Board Remedies}

Ironically, earlier Supreme Court decisions reflect a proper appli-

${ }^{78}$ Id. at 2782-83 (footnote and citations omitted) (quoting United States v. Shimer, 367 U.S. $374,382(1961))$.

7941 U.S. 488 (1979).

${ }^{80} \mathrm{Id}$. at 496 (citations omitted) (quoting NLRB v. Insurance Agents, 361 U.S. 477, 499 (1960) and NLRB v. Erie Resistor Corp., 373 U.S. 221, 236 (1963) (quoting NLRB v. United Steelworkers, 357 U.S. 357, 362-63 (1958))). (1982).

See National Labor Relations (Wagner) Act § 10(c), 29 U.S.C. § 160(c)

S2 See supra note 15 . 
cation of these general principles of administrative law and demonstrate that wide latitude has traditionally been granted the Board in these matters. The Board has long issued remedies that, like the backpay order in Sure-Tan, are based to some degree on speculation. ${ }^{83}$ Such remedies have been approved by the courts especially where they were found to serve or accommodate both the goals of the Act and considerations of equity. ${ }^{84}$

$N L R B$ v. Seven-Up Bottling Co. ${ }^{85}$ illustrates this point. At issue in Seven-Up was the manner in which the Board calculated the amount of backpay awarded to eleven unlawfully discharged employees. ${ }^{86}$ The Board had applied its "Woolworth Company" formula, under which a discriminatee's loss of pay-what she would have earned absent the discriminatory discharge minus what she earned in post-discharge employment-is computed on the basis of separate calendar quarters, or portions thereof, from the date of discharge to the date of reinstatement. ${ }^{87}$ Under this formula, excess earnings in one quarter from postdischarge employment do not reduce the employer's backpay liability for earnings in previous quarters. The court of appeals in Seven-Up rejected the Board's remedy, reasoning that, since the discharged employees had never been compensated for work on a quarterly basis, the Board's method of calculating backpay might produce a windfall for the discriminatees. As the court of appeals saw it, "The employee is entitled to be made whole, but no more."88 The court modified the Board's order so that backpay would be measured on the basis of the entire period of unemployment. ${ }^{89}$

The Board's manner of computing backpay was, however, upheld by the Supreme Court. ${ }^{90}$ The Seven-Up Court, applying the standard

83 See infra note 97.

84 For example, in NLRB v. Gissel Packing Co., 395 U.S. 575 (1969), the Board remedied employer unfair labor practices by certifying the union on the basis of a majority showing in authorization cards and by ordering the employer to bargain with the union. The Supreme Court upheld this remedy. See supra text accompanying notes 6165. Such a remedy was speculative because it assumed that, but for the unfair labor practices by the employer, the employees would have voted in favor of the union. The Gissel Court relied heavily on the Board's competence and expert judgment, which give it the ability to devise remedies necessary to undo the serious harm to the collective bargaining process caused by unfair labor practices and also to effectuate the main purposes of the Act. See Gissel, 395 U.S. at 614-15.

88344 U.S. 344 (1953).

se Id. at 346.

${ }^{87}$ See F.W. Woolworth Co., 90 N.L.R.B. 289, 292-93 (1950).

83 NLRB v. Seven-Up Bottling Co., 196 F.2d 424, 427-28 (5th Cir. 1952), rev'd, 344 U.S. 344 (1953).

89 See id. at 427.

80 See Seven-Up, 344 U.S. at 352. The dissent in Seven-Up noted that "[t]he net result will probably be that this employee will receive a total amount of [interim] 
for determining the validity of Board remedies developed in Virginia Electric \& Power Co. v. NLRB, ${ }^{91}$ found that the Woolworth Co. formula was not a " "patent attempt to achieve ends other than those which can fairly be said to effectuate the policies of the Act." "92 Rather, the formula was found to be an attempt, properly within the Board's authority, to fashion a backpay remedy that would not adversely affect the companion remedy of reinstatement. ${ }^{93}$ Were backpay not computed on a quarterly basis, an employer might well find it to its advantage to delay proceedings and to postpone offers of reinstatement. The Court reasoned that "the Board may be mindful of the practical interplay of two remedies, back pay and reinstatement, both within the scope of its authority." ${ }^{\prime 84}$ Further, the Court argued for deference to the Board's resolution of the issue: "[T]he Board's conclusions may 'express an intuition of experience which outruns analysis and sums up many unnamed and tangled impressions .....'

Backpay awards under Section 10(c) generally include "the moneys, whether gratuitous or not, which it is reasonably found that the employee would actually have received in the absence of the unlawful discrimination." ${ }^{98}$ Two conclusions follow from this rule. First, the Board may order backpay to which an employee would not have been contractually entitled. Second, though it may be difficult-in some cases, such as Sure-Tan, nearly impossible-to reconstruct precisely what the financial situation of an aggrieved employee would have been but for the unlawful discharge, Congress has entrusted the Board with discretionary powers to achieve a reasonable, if only approximate, restoration. ${ }^{97}$ While the Board is expected to estimate as closely as possible

earned income, plus backpay, which exceeds what he would have earned at his regular job." 344 U.S. at 353 (Douglas, J., dissenting). The Board continues to use the Woolworth Co. formula. See, e.g., Sure-Tan, Inc., 234 N.L.R.B. 1187, 1188 (1978), enforced as modified, 672 F.2d 592 (1982), aff d in part and rev'd in part, 104 S. Ct. 2803 (1984).

91 319 U.S. 533 (1943).

92 Seven-Up, 344 U.S. at 347 (quoting Virginia Electric, 319 U.S. at 540).

os See id. at 347-48 (tracing the history of the Woolworth Co. formula).

ot Id. at 348 .

95 Id. (quoting Chicago, B. \& Q. Ry. v. Babcock, 204 U.S. 585, 598 (1907)).

${ }_{98}$ Nabors v. NLRB, 323 F.2d 686, 690 (5th Cir. 1963) (emphasis added), cert. denied, 376 U.S. 911 (1964).

${ }^{97}$ See, e.g., McCann Steel Co. v. NLRB, 570 F.2d 652, 655 (6th Cir. 1978) (Overtime pay ordinarily received by an employee may be included in backpay.); NLRB v. Otis Hosp., 545 F.2d 252, 257 (1st Cir. 1976) (expected wage increase and interest included in backpay award); NLRB v. Madison Courier, Inc., 472 F.2d 1307, 1312 n.9 (D.C. Gir. 1972) (Christmas bonuses included in backpay); NLRB v. Mooney Aircraft, 375 F.2d 402, 403 (5th Cir.) (per curiam) (holding that the Board can infer that an employee would have been promoted and award backpay accordingly), cert. denied, 389 U.S. 859 (1967); NLRB v. Miami Coca-Cola Bottling Co., 
the earnings that the discriminatee would have received but for the unlawful discharge, the Board may grant imprecise or speculative backpay awards if the unfair labor practice itself makes a more exact measurement impossible, or if the need to vindicate the primary goals of the Act makes the more certain, and therefore "safer," remedies inappropriate. ${ }^{88}$ As the Supreme Court has stated, "The most elementary conceptions of justice and public policy require that the wrongdoer shall bear the risk of the uncertainty which his own wrong has created." This notion is particularly applicable to Sure-Tan. Any backpay granted to the discriminatees would necessarily have been uncertain, but meaningful vindication of the rights violated by the employer required a speculative remedy. ${ }^{100}$

360 F.2d 569, 572 (5th Cir. 1966) (safe driving award included in backpay); Isis Plumbing \& Heating Co., 138 N.L.R.B. 716, 719 (1962) (The Board may add interest to a backpay award.), rev'd on other grounds, 322 F.2d 913 (9th Cir. 1963).

Of course, allowing admittedly inexact compensatory relief does not always work to the advantage of the unlawfully discharged employee. There is, for instance, no attempt to compensate the discriminatee for incidental injuries such as "his hardship during the period of litigation, his lost opportunity to use the income he would have earned, perhaps the loss of his home or car for failure to make timely payments." Note, NLRB Power to Award Damages in Unfair Labor Practice Cases, 84 HaRv. L. Rev. 1670, 1674-75 (1971) (footnote omitted); see also St. Glair v. Local 15, Int'l Bhd. of Teamsters, 422 F.2d 128, 132 (6th Cir. 1969) (finding the union not liable for humiliation and embarrassment or the loss of a union member's home to a mortgage holder.).

${ }^{98}$ See Note, supra note 49 , at 80 (The Board may go beyond a minimal correction to effectuate the policies of the Act.); see also Phelps Dodge Corp. v. NLRB, 313 U.S. 177, 193 (1941) (finding that the reinstatement of a discriminatee may be ordered even when it is not needed to redress the workers' economic loss).

B2 Bigelow v. RKO Radio Pictures, 327 U.S. 251, 265 (1946); see also J. Truett Payne Co. v. Chrysler Motors Corp., 451 U.S. 557, 566-67 (1981) ("[I]t does not come " "with very good grace" ' for the wrongdoer to insist upon specific and certain proof of the injury which it has itself inflicted.") (quoting Hertzel v. Baltimore \& O.R.R., 169 U.S. 26, 39 (1898) (quoting United States Trust Co. v. O'Brien, 143 N.Y. 284, 289, 38 N.E. 266, 267 (1894))) (citations omitted).

100 See Virginia Electric, 319 U.S. at 543 ("It is . . . wrong to fetter the Board's discretion by compelling it to observe conventional common law or chancery principles in fashioning .... an order, or to force it to inquire into the amount of damages actually sustained.").

The Sure-Tan Court itself distinguished between "speculative" and "punitive" remedies, though its disposition of the case enabled it to avoid having to decide whether the backpay order was one or the other. Thus, the Court was kept from "the "bog of logomachy' as to what is 'remedial' and what is 'punitive." Sure-Tan, 104 S. Ct. at 2816 n.14 (quoting Seven-Up, 344 U.S. at 348). Remedies that are "punitive" are beyond the authority of the Board and will not be enforced. See Republic Steel Corp. v. NLRB, 311 U.S. 7, 11 (1940) (Congress did not intend "to vest in the Board a virtually unlimited discretion to devise punitive measures, and thus to prescribe penalties or fines which the Board may think would effectuate the policies of the Act."); see also infra notes 178-82 and accompanying text (discussing the prohibition of punitive remedies). Thus, the Board's remedy must "bear appropriate relation to the policies of the Act." Seven-Up, 344 U.S. at 348; accord Virginia Electric, 319 U.S. at 540; see also D. McDowell \& K. HuHn, NLRB Remedies for Unfair Labor Practices 1215 (1976) (discussing the punitive/remedial distinction). A "speculative" remedy is by 
In light of these considerations, it is evident that the Sure-Tan Court erred in modifying the remedy adopted by the Board. There are two notable flaws in its analysis. First, the Court deemphasized the tolerance of inexact and approximate backpay awards that has been traditionally granted to the Board. Second, the Court took pains to exaggerate the degree of speculativeness inherent in the particular backpay award that the court of appeals authorized in Sure-Tan.

Although the court of appeals did not cite empirical data to support the reasonableness of its assumption that the unlawful discharge deprived the Sure-Tan discriminatees of six months' employment, supporting evidence certainly does exist. The NLRB, in its brief to the Sure-Tan Court, presented the results of a study showing that the average length of residence in the United States for undocumented aliens, prior to their apprehension by the INS, was 2.5 years. ${ }^{101}$ This study showed further that more than thirty-six percent of arrested aliens had resided in this country for more than three years and that ten percent had resided here for more than six years. ${ }^{102}$ In light of these statistics, and even without knowledge of how long any of the five discriminatees in Sure-Tan had been in or planned to stay in the United States, the court of appeals' estimation was reasonable, if not conservative.

The Sure-Tan Court may, however, have considered general statistical data insufficient for determining backpay awards in particular cases. The backpay remedy was found to be too speculative because there was no "evidence as to the circumstances of the individual employees." 103 The Seventh Gircuit's six-month period was designed to estimate the length of time that the employees would have continued working had their employer not reported them. Given that this estimate is based on a counterfactual assumption-that no reporting occurred-speculation is the only way in which a backpay order could be fashioned. In other words, the evidence required by the Court simply does not exist; the employees were forced to leave the United States, and the length of time they would have remained absent the unfair labor practice is unknowable. Insisting on such evidence precludes remedial action whenever the employer has, in effect, destroyed the evidence.

no means necessarily "punitive." See Virginia Electric, 319 U.S. at 544 ("The fact that the Board may only have approximated its efforts to make the employees whole . . . does not convert this reimbursement order into the imposition of a penalty.").

${ }^{101}$ See Brief for the National Labor Relations Board at 44 n.42, Sure-Tan (citing U.S. Dep'T of Labor, The ChaRacteristics and Role of Illegal Aliens in THE U.S. LABOR MARKET 81 (1976)).

102 See id.

103 Sure-Tan, 104 S. Ct. at 2814. 


\section{Privileging Private Law Contractualism over Statutory Public Rights}

The most important goals underlying the NLRA are outlined in section 1 of the Act, and it is the Board that is primarily entrusted with the task of effectuating those goals. ${ }^{104}$ Two goals stand out as fundamental: ${ }^{105}$ encouraging the practice and procedure of collective bargaining, and protecting the exercise by workers of full freedom of association, self-organization, and designation of representatives of their own choosing. ${ }^{106}$ These objectives simply cannot be realized if the agency administering the Act lacks the power to stop and prevent unfair labor practices. ${ }^{107}$

In reaching its decision in Sure-Tan, the Court made two crucial errors. First, the Court mischaracterized the compensatory concerns of the Act as policy objectives. The Court then implicitly endowed these newfound policies with a level of significance previously reserved for the "fundamental" policies of the Act. Second, and somewhat paradoxically, the Court unduly confined the Board's ability to fashion remedial awards, even when remedial discretion is necessary to advance compensatory objectives. Unarticulated contractualist assumptions serve to explain the Court's unwarranted conclusions.

104 See National Labor Relations (Wagner) Act $\S 1,29$ U.S.C. $\S 151$ (1982). As one commentator has argued, the "language of section 10(c) commanding the Board to fashion such remedies 'as will effectuate the policies of this Act' and the similar command in section 9(b) that the 'appropriateness' of a unit for collective bargaining purposes is to be measured against the policies of the Act" show "[t]hat the policy statement of Section 1 is not mere surplusage safely to be ignored" in interpreting the Act. Klare, supra note 46, at 281 n.51 (citations omitted).

${ }^{105}$ Because of the indeterminacy of the text and legislative history of the Act, especially in light of the turbulent political circumstances surrounding its passage, the list of policy goals and objectives arguably informing the enactment of the NLRA varies significantly among the commentators. See, e.g., Cox, The Duty to Bargain in Good Faith, 71 HARv. L. Rev. 1401, 1407 (1958) (arguing that the most important purpose of the Wagner Act was equalization of bargaining power); Summers, Past Promises, Present Failures, and Future Needs in Labor Legislation, 31 Buffalo L. REv. 9, 12 (1982) (One purpose of the NLRA was to encourage collective bargaining as a method of "provid[ing] a measure of industrial democracy and individual justice."). One author has discerned six main aims of the Act: industrial peace, collective bargaining, equalization of bargaining power, employee freedom of association for bargaining purposes, prevention of economic crises due to under-consumption, and industrial democracy. See Klare, supra note 46, at 281-85.

108 See National Labor Relations (Wagner) Act § 1, 29 U.S.C. § 151 (1982).

107 Section 10(a) of the NLRA empowers the Board "to prevent any person from engaging in any unfair labor practice . . a affecting commerce." 29 U.S.C. $\S 160$ (a) (1982). 


\section{A. Sure-Tan's Elevation of Compensatory Policy}

Compensatory relief has traditionally been viewed as a vehicle for advancing the central policy goals of the NLRA-a means to an end-and not as an end in itself. ${ }^{108}$ This view comports with the statute's express language. ${ }^{109}$ Yet the Court in Sure-Tan characterized compensation as a discrete policy goal-as an end in itself. Such a formulation is unprecedented. As the Court stated in Consolidated Edison Co. v. NLRB, "110 "The power to command affirmative action . . . is to be exercised in aid of the Board's authority to restrain violations and as $a$ means of removing or avoiding the consequences of [a] violation where those consequences are of a kind to thwart the purposes of the Act."111 As between compensating victims and deterring future violations, the Court has declared the latter to be the principal objective: "The power to order affirmative relief under $\S 10(c)$ is merely incidental to the primary purpose of Congress to stop and to prevent unfair labor practices."112 Backpay awards, it noted, may only "incidentally provide some compensatory relief to victims of unfair labor practices."118

108 The Act has not been construed to give the Board authority to compensate unlawfully discharged employees for all damages incidental to the unfair labor practice. See Note, NLRB Power to Award Damages in Unfair Labor Practice Cases, 84 HARv. L. REv. 1670, 1683-87 (1971). There are situations in which a discharge may be tortious and yet not be in violation of federal labor law. See Automobile Workers v. Russell, 356 U.S. 634, 645 (1938) ("There is nothing inconsistent in holding that an employee may recover lost wages as damages in a tort action under state law, and also holding that the award of such damages is not necessary to effectuate the purposes of the Federal Act.").

108 See National Labor Relations (Wagner) Act § 10(c), 29 U.S.C. § 160(c) (1982) (empowering the Board to take such remedial action "as will effectuate the policies of this Act").

110305 U.S. 197 (1938).

111 Id. at 236 (emphasis added); see also Virginia Elec. \& Power Co. v. NLRB, 319 U.S. 533, 541 (1943) (An order to reimburse unlawfully deducted checked-off dues, like a backpay award for discriminatorily discharged employees, assures all employees that "an employer may not with impunity" violate the Act.). To effectuate the policies of the Act, the Board may fashion its remedy so as to make workers "more confident in the exercise of their statutory rights." Id.

${ }_{112}$ UAW v. Russell, 356 U.S. 634, 642-43 (1958) (emphasis added).

11 Id. at 645; cf. Phelps Dodge Corp. v. NLRB, 313 U.S. 177, 197 (1941) ("Making the workers whole for losses suffered on account of an unfair labor practice is part of the vindication of the public policy which the Board enforces.") (emphasis added).

One early observer commented that, as part of its basic role in carrying out the purposes of the Act, the backpay provision was intended to perform a "deterrent function-to discourage employers from engaging in unfair labor practices by requiring them to make good the losses which their violations of the law have caused." Note, Back Pay Orders Under the National Labor Relations Act, 48 YALE L.J. 1265, 1265 (1939); see also NLRB v. Carlisle Lumber Co., 99 F.2d 533, 537 (9th Cir. 1938) 
The Seventh Circuit's ruling in Sure-Tan was firmly rooted in a recognition of compensatory relief as a mechanism for effectuating the policies of the Act. ${ }^{114}$ In the Supreme Court's decision, except for a passing reference in a footnote, ${ }^{115}$ deterrence and prevention gave way to what the Court described as "the general reparative policies of the NLRA."116

It is possible that the Court actually believed that the Board's cease-and-desist order satisfied the NLRA's requirement that remedies make employees "more confident in the exercise of their statutory rights." 117 There is, however, a seemingly disingenuous naiveté in the Court's position that cease-and-desist orders alone create "a significant deterrent against future violations of the Act."118 Cease-and-desist orders in general may have some deterrent effect, ${ }^{119}$ but the Court's claim

("TT]he provisions ... . were designed to insure that an employer would cease unfair labor practices."); NLRB v. Biles Coleman Lumber Co., 98 F.2d 18, 23 (9th Cir. 1938) (Section 10(c) "is designed to vindicate the policy of the Act and to compel observance of its purpose and spirit.").

The Board's mandate to effectuate Congress's intention to stop and prevent unfair labor practices by devising, where necessary, effective deterrents does, of course, have limits. Section 10(c) has been construed not to confer upon the Board "a punitive jurisdiction" enabling it to inflict upon an employer that violates the Act "any penalty it may choose . . . even though the Board be of the opinion that the policies of the Act might be effectuated by such an order." Consolidated Edison Co. v. NLRB, 305 U.S. 197, 235-36 (1938); see also NLRB v. Coats \& Clark, Inc., 241 F.2d 556, 562 (5th Cir. 1957) (holding that an order reinstating an employee who was not entitled to reinstatement was punitive rather than remedial in nature and therefore not permissible).

114 See NLRB v. Sure-Tan, 672 F.2d at 606 ("[W]e believe six months' backpay is a minimum amount for purposes of effectuating the policies of the Act.").

116 Sure-Tan, 104 S. Ct. at $2815 \mathrm{n} .13$ ("[T]oday's decision leaves intact the cease and desist order . . . . [The] threat of contempt sanctions thereby provides a significant deterrent against future violations ....").

${ }^{116} I d$. at 2814 (footnote omitted).

117 Virginia Elec. \& Power Co. v. NLRB, 319 U.S. 533, 541 (1943).

118 Sure-Tan, 104 S. Ct. at 2815 n.13.

119 Traditional cease-and-desist orders subject the violator to contempt proceedings if similar violations occur in the future. For a general discussion of the importance that the Court attaches to such orders, see NLRB v. Express Publishing Co., 312 U.S. 426 (1941). The Supreme Court has, however, recognized the ineffectiveness of cease-anddesist orders standing alone:

If employers faced only the prospect of an injunctive order, they would have little incentive to shun practices of dubious legality. It is the reasonably certain prospect of a backpay award that "provide[s] the spur or catalyst which causes employers and unions to self-examine and to self-evaluate their employment practices ...."

Albemarle Paper Co. v. Moody, 422 U.S. 405, 417-18 (1975) (quoting United States v. N.L. Indus., 479 F.2d 354, 379 (8th Gir. 1973)). The Albemarle Court was discussing the backpay provision of Title VII, 42 U.S.C. $\$ 2000$ (e)-5(g) (1982), but noted that it "was expressly modeled on the backpay provision of the [NLRA]." Albemarle, 422 U.S. at 419 (footnote omitted). 
of their deterrence value with respect to the particular facts of SureTan is an exercise in wishful thinking. It is difficult to imagine how the discriminatees' fellow employees-let alone the discriminatees themselves-might be assured of the meaningfulness of the NLRA's protection by the knowledge that the employer's flagrant violation of the Act had neither resulted in the reinstatement of the discharged employees nor cost the employer a single dime in backpay. Consequently, the imposition of a cease-and-desist order hardly responds to the challenge for a creative remedy that was presented by this extraordinary case. The Sure-Tan Court itself confessed that a backpay order such as the one it rejected would "afford both more certain deterrence against unfair labor practices and more meaningful relief for the illegally discharged employees."120

\section{B. Sure-Tan's Use of Private-Law Contract Ideology to Restrain Compensatory Relief}

Even more troublesome than the Sure-Tan Court's mischaracterization of reparation as an independent policy concern is the Court's narrow view of what the Board may deem to be appropriate reparation in a given situation. Once again, the Court failed to see section 10(c) as part of a general program designed to protect and vindicate the rights of employees to associate freely for the purpose of collective bargaining. Though the Court acknowledged the fundamental axiom of judicial review under the Act-that appellate courts "should not substitute their judgment for that of the Board in determining how best to undo the effects of unfair labor practices"121 - it proceeded to do just that when it formulated the guidelines for the future calculation of backpay awards.

The Court declared that a valid backpay award must be "sufficiently tailored to the actual, compensable injuries suffered by the discharged employees." ${ }^{\prime 22}$ This result was compelled by the Court's stated belief that "it remains a cardinal, albeit frequently unarticulated assumption, that a backpay remedy must be sufficiently tailored to expunge only the actual, and not merely [the] speculative, consequences of the unfair labor practices."12s Guided by "unarticulated assumptions," the Court in Sure-Tan radically reduced-to the formalistic level of compensating "actual" injuries-the Board's discretionary au-

120 Sure-Tan, 104 S. Ct. at 2815 n.13.

121 Id. at 2813; accord Phelps Dodge Corp. v. NLRB, 313 U.S. 177, 194 (1953) ("T T] he relation of [a] remedy to policy is peculiarly a matter for administrative competence .....").

122 Sure-Tan, 104 S. Ct. at 2814.

${ }^{123} I d$. at 2813-14 (citation omitted). 
thority to "prevent any person from engaging in any unfair labor practice,"124 to undo the "effects" of unfair labor practices, and to compel wrongdoers to take affirmative action that will support the purposes of the Act.

By so confining the backpay remedy, the Court implicitly equated the "effects" of violations of the Act with narrowly defined, demonstrable injuries. Furthermore, by elevating reparation to the level of an independent, overriding policy goal of the Act's remedial mandate, the Court abandoned the Act's essential goal of preventing unfair labor practices as well as the Court's own notion that remedies should prevent violators of the Act from enjoying the fruits of their wrongdoing. ${ }^{125}$ The result of the Court's departure is an unparalleled anomaly: five discriminatorily discharged employees and an employer whose sole reminder of violating the Act is a cease-and-desist order. ${ }^{128}$ The Court clearly failed to avoid the long-recognized "danger that purely 'compensatory' remedies may fail in some cases to effectuate fully the purposes of the Act."12z In an unlawful discharge case such as Sure-Tan, the danger is that "an order granting reinstatement with backpay may amount to no more than 'a license fee for union busting." "128

Because of an undue emphasis on private-law and contract-law values, the Sure-Tan Court lost sight of NLRA policy goals. To understand fully how the Court reached such an anomalous result, one must examine the basic contractualist premises underlying the Sure-Tan decision.

Contractualism refers to a set of assumptions ${ }^{129}$ and values con-

${ }^{124}$ National Labor Relations (Wagner) Act $\S 10(a), 29$ U.S.C. $§ 160$ (a) (1982).

126 See D. MCDowell \& K. HuHN, supra note 100, at 13-14 (noting that the Supreme Court has upheld remedies "necessary to prevent future enjoyment of the fruits of an unfair labor practice") (footnote omitted).

${ }^{128}$ This is the result of the Board's original order, which the Court found acceptable. See Sure-Tan, $104 \mathrm{~S}$. Ct. at 2814 . A similar result would be reached only in a case in which an unlawfully discharged employee immediately secured substantially equivalent employment and began working at the new job on the day following her unlawful termination. On the day following their discharge, however, the discriminatees in Sure-Tan were not working at all; they were still on a bus bound for Mexico.

${ }_{127}$ United Steelworkers v. NLRB, 646 F.2d 616, 630 (D.C. Cir. 1981).

${ }^{128}$ Id. (quoting Staff of Subcomm. ON THe NLRB, House Comm. on EduCation and Labor, 87Th CoNG., 1ST Sess., Administration of the LaborManagement Relations ACt by The NLRB 2 (Comm. Print 1961) (footnote omitted)).

128 The basic assumptions of the contractualist framework are that

all values are arbitrary, subjective, and personal; that society is an artificial aggregation of autonomous individuals who come together solely for the instrumental purpose of maximizing personal satisfactions; that the state should do no more than facilitate the orderly quest for such satisfactions; and that, because values are arbitrary and subjective, only the con- 
cerning law, politics, and justice that is rooted in a system of generalized commodity production. The linchpin of the contractualist framework is the doctrine of freedom of contract. ${ }^{130}$ It assumes nominal bargaining equality between the parties" ${ }^{131}$ and extols "the social virtue of uncompelled private-ordering of most transactions: the right of private citizens to establish the legal incidents and standards governing most of their relationships." 132 The mainstay of contractualist justice is the enforcement of the parties' agreement, that is, the vindication of recognized expectations. The value of the exchange that will be enforced is precisely that which is laid out in the agreement-nothing more and nothing less. To that end, contractualism requires that the value of the subject matter of the exchange be capable of accurate measurement.

In modern American labor law, the largely unexamined, unarticulated premises of the contractualist framework shape the concept of appropriate remedies under the NLRA and also influence what subjects fall within the scope of bargaining, ${ }^{133}$ what role arbitration plays in a system of collective bargaining, ${ }^{134}$ and what economic weapons may be used by capital and labor. ${ }^{135}$

The passage of the NLRA led many to believe that contractualism's role in labor law would be greatly diminished. ${ }^{136}$ Indeed, the Act has been cited as part of a trend of "developments in public policy

currence, actual or constructive, of individual desires can provide standards of ethical obligation.

Klare, supra note 46, at $295 \mathrm{n} .95$ (citation omitted). These assumptions have been challenged. It has been argued that "the good is not arbitrary and wholly subjective [and] that needs and values can arise from shared social experience apart from mere coincidence or situations of domination." Id. at 296 n.97.

130 Note that "[ $t$ ]he amount of freedom created by the system of freedom of contract depends on the structure of economic power, yet differences of economic or class power are ordinarily either ignored or regarded as legitimate in contractualist jurisprudence." Id. at 296 (footnote omitted).

131 Writing over 50 years ago, Morris Cohen criticized supporters of contractualism who assert that "as each man knows best what will please him most, a contract in which two parties freely express what they prefer is the best way of achieving the greatest good" for "blandly ignor[ing] the fact that though men may be legally free to make whatever contract they please, they are not actually or economically free." Cohen, The Basis of Contract, 46 HaRv. L. REv. 553, 563 (1933).

132 Klare, supra note 46, at 295 (footnote omitted). The employer-employee wage bargain, in which the employee trades her labor for a salary, is one such transaction.

See id. at 297.

1ss See infra note 149 (discussing the duty to bargain).

134 See, e.g., Stone, The Post-War Paradigm in American Labor Law, 90 Yale L.J. 1509 (1981) (discussing how the ideology of "industrial pluralism" applied to the NLRA actually shields the private ordering of the workplace from government intervention).

1ss See infra notes 147 \& 161.

136 See Klare, supra note 46, at 293. 
which systematically robbed contract of its subject matter."137 Businesses felt that the Act would lead to government intervention in the traditional private ordering of the workplace and, with that, to interference with the prerogative of managerial control over the means of production. ${ }^{138}$ Such concerns were raised about the "radical potential" of the Act's underlying premises, premises that suggested wealth redistribution and participatory democracy. ${ }^{13 \theta}$ The worst of these fears, however, did not materialize. Despite the Act's anticontractual language, ${ }^{140}$ the Supreme Court's early interpretation committed the Act to a contractualist, private-ordering framework. ${ }^{141}$

The Court's decision in NLRB v. Jones $\mathbb{E}$ Laughlin Steel Corp., ${ }^{142}$ upholding the constitutionality of the NLRA, reveals the Court's initial determination to keep contractualism entrenched in the workplace. The Court affirmed the rights of employees both to bargain collectively for wages and to choose freely their bargaining representative. ${ }^{143}$ Once it acknowledged these basic rights, however, the Court adopted a contractualist orientation: "The Act does not compel agreements between employers and employees. It does not compel any agreement whatever. It does not prevent the employer 'from refusing to make a collective contract and hiring individuals on whatever terms' the employer 'may by unilateral action determine." "144 In short, the Court refused to allow the Board to inquire into the "substantive justice of labor-management relations or the fairness of the wage-bargain."145 Nevertheless, despite its strong contractualist interpretation of the Act, the Court in Jones $\mathcal{E}$ Laughlin Steel did uphold the Act's incursion

197 L. Friedman, Contract Law in America 24 (1965), quoted in Klare, supra note 46 , at 293 n.88.

198 See Klare, supra note 46 , at $287-88$.

139 See id. at 287.

140 See, e.g., National Labor Relations (Wagner) Act $\S 8(\mathrm{a})(3), 29$ U.S.C. $\S 158(a)(3)$ (1982) (limiting an employer's right to hire or fire); id. \& 8(a)(5), 29 U.S.C. \& 158(a)(5) (1982) (creating a duty to bargain with the employees' chosen representative). At the time the NLRA was passed, some feared that these provisions would lead to state scrutiny of the substantive terms of labor contracts. See Klare, supra note 46, at 294.

141 See Klare, supra note 46, at 294-95. See generally id. at 298-310 (discussing early cases adopting contractualism under the NLRA).

142301 U.S. 1 (1937).

143 See id. at 33-34.

144 Id. at 45 (quoting Virginian Ry. v. System Fed'n, No. 40, 300 U.S. 515, 549 n.6 (1937)).

145 Klare, supra note 46 , at 300 . The Jones $\mathcal{E}$ Laughlin Steel Court's residual contractualism, apparent in the firmness of its belief that the Act did not encroach upon an employer's right to enter into individual employment contracts, has been revised in subsequent decisions. See, e.g., J.I. Case Co. v. NLRB, 321 U.S. 332 (1944) (rejecting individual bargaining in favor of the principle of exclusive representation). 
into an area previously considered the realm of individualized private arrangements: employers would not be allowed to interfere with their "employees' decision whether to adopt a collective posture for wagebargaining or their choice of a representative for [this] purpose."146

Though the Jones $\&$ Laughlin Steel decision was followed by several NLRA decisions reaffirming the Court's commitment to contractualism, ${ }^{\mathbf{1 4 7}}$ other early decisions made inroads into contractualistic formalism. ${ }^{148}$ This continuing tension between contractualism and anticontractualism is the foremost feature in a long line of Supreme Court labor decisions. ${ }^{14 \theta}$ In Sure-Tan, contractualism enjoyed one of its finest 34).

140 Klare, supra note 46, at 298 (citing Jones \& Laughlin Steel, 301 U.S. at 33-

147 See, e.g., NLRB v. MacKay Radio \& Tel. Co., 304 U.S. 333, 345-46 (1938) (establishing the right of employers to replace striking workers permanently so long as the employer did not induce the strike by committing unfair labor practices). The decision in MacKay Radio reinforces the notion that

the Act is disinterested in the substantive justice of the labor contract since it taught that not only would the wage-bargain not ordinarily be subject to substantive scrutiny, but also that the economic combat of the parties had replaced a "meeting of the minds" as the moral basis of labor contractualism.

Klare, supra note 46 , at $302-03$.

${ }^{148}$ See, e.g., NLRB v. Falk Corp., 308 U.S. 453, 461-62 (1940) (denying an employer-dominated union a place on a representation election ballot). The Falk Court sustained the Board's determination that a disestablished company-dominated union should be kept off the ballot in a representation election because of the union's inability to "emancipate itself from habitual subservience to its creator." Id. at 461. The Court and the Board agreed that the preservation of the "complete freedom of choice guaranteed by § 7" required that the company-dominated union be excluded. Id. The Court's reasoning infuses into the free choice concept a "substantive content, determined by the history of the workplace, not merely a formal content determined by the mechanics of secret balloting." Klare, supra note 46, at 305 (footnote omitted).

149 See Klare, supra note 46, at 293-310. Karl Klare believes that cases along the Falk line actually "did not attack contractualism as such." Id. at 306. Instead, the Court was attempting to establish the necessary "preconditions of 'true' or 'actual' private-ordering; [it was trying] to make contractualism work." Id. "There [was] no intimation in [the Court's reasoning] that, once the preconditions of 'actual liberty of contract' were realized, the law would inquire into the substantive results of bargaining." Id. at 306-07.

The real tension between contractualism and anti-contractualism is brought out by the duty to bargain set forth in section 8(a)(5) of the NLRA, 29 U.S.G. § 158(a)(5) (1982). Though the legislative history indicated that the duty required nothing more than physically meeting and discussing, "it was clear . . . that the duty to bargain would have to mean more, if it were to mean anything . . . " Klare, supra note 46, at 307. The language of section $8(a)(5)$ is open to conflicting readings. Under one, the employer must bargain with regard to the subjects included in section 9(a), 29 U.S.C. $\S 159$ (a) (1982). See Cox \& Dunlop, Regulation of Collective Bargaining by the $\mathrm{Na}$ tional Labor Relations Board, 63 HARv. L. Rev. 389, 403-04 (1950). Employers may, however, bargain in good faith on the decision

as to whether a specific term or condition of employment (1) should be established by the collective agreement; or (2) should be fixed periodically by joint management-union determination within the framework of the 
triumphs. ${ }^{100}$

Contractualist concerns permeate the Court's opinion in Sure-Tan and explain the Court's unacceptable equation of a "just backpay remedy"151 with one sufficiently tailored to "actual losses" and "compensable injuries."162 By so confining the appropriate remedy, the Court embraced the antiquated contract notion that "damages ... must "be shown by clear and satisfactory evidence' to have been actually sustained and 'be shown with certainty and not left to speculation or conjecture." "15s Guided by a contractualist framework, the Court chose a

contract; or (3) should be left to management's discretion or individual bargaining without the intervention of the bargaining agent.

Id. at 404. Under the second reading, "an employer must bargain collectively with respect to each subject embraced within section 9(a)." Id. Section 8(d) was designed to clarify what the duty means. See National Labor Relations (Wagner) Act $\S 8(d), 29$ U.S.C. $\S 158$ (d) (1982). However, section 8(d), when read in conjunction with section 9(a), "can easily be read as a command to bargain upon each and every subject embraced within the critical phrase [of section 9(a), which speaks of] rates of pay, wages, hours and other conditions of employment." A. Cox, D. BoK \& R. GoRman, supra note 55, at 435. It is unlikely, as the words of the Senate Labor Committee's Chairman reveal, that the NLRA was thought to interfere with the substance of the collective bargain:

When the employees have chosen their organization, when they have selected their representatives, all the bill proposed to do is to escort them to the door of their employer and say, "Here they are, the legal representatives of your employees." What happens behind those doors is not inquired into, and the bill does not seek to inquire into it.

79 CoNG. Rec. 7660 (1935) (statement of Sen. Walsh). Though this statement would seem to leave the employer that bargains with its employees' representative free to "fight out" the particular terms of the collective agreement, see A. Cox, D. BoK \& R. GoRMaN, supra note 55, at 435, the law has been interpreted otherwise. See, e.g., NLRB v. Katz, 369 U.S. 736 (1962) (holding that it is a violation of section 8(a)(5) for an employer that is negotiating with a union to institute unilateral changes regarding mandatory subjects of collective bargaining).

150 The cases known collectively as the Steelworkers Trilogy-United Steelworkers v. Enterprise Wheel \& Car Corp., 363 U.S. 593 (1960); United Steelworkers v. Warrior \& Gulf Navigation Co., 363 U.S. 574 (1960); United Steelworkers v. American Mfg. Co., 363 U.S. 564 (1960)-established the federal policy favoring private arbitration for resolving labor disputes. These cases represent a victory for the idea that labor relations should be confined as much as possible within the sphere of private, localized relations, shielded from national social policy considerations. See, e.g., United Technologies Corp., 268 N.L.R.B. 557 (1984) (deferring to the grievance arbitration process provided in the parties' collective bargaining agreement).

151 Sure-Tan, 104 S. Ct. at 2813 n.10.

152 Id. at 2814. The Court never explicitly defines "sufficiently tailored"; however, the Court's emphasis on an "actual" damage standard is implied in its assertion that the six-month backpay award was "merely speculative" and "not sufficiently tailored." Id.

153 E. Farnsworth \& W. Young, Cases and Materials on Contracts 634 (3d ed. 1980) (quoting Griffin v. Colver, 16 N.Y. 489, 491 (1858)). Compare the SureTan standard: "[A] backpay remedy must be sufficiently tailored to expunge only the actual, and not merely [the] speculative, consequences of the unfair labor practices." 104 S. Ct. at 2813-14 (citation omitted). 
remedy that, although perhaps acceptable in a private contracts dispute, ${ }^{154}$ failed to account for the employees' rights ${ }^{155}$ or to effectuate the central goals of the Act. ${ }^{156}$ The result left the discriminatees with no compensatory relief ${ }^{167}$ and no real prospect for reinstatement, ${ }^{158}$ and the employer with only the mild reprimand of a cease-and-desist order. ${ }^{150}$

Though the problem of imposing a strongly contractualist reading on the NLRA is not new-nor, for that matter, is the problem of applying other pre-NLRA notions of justice and propriety in labor law cases $^{100}$ - it is difficult to recall a case in which so glaringly inequitable a result was tolerated. ${ }^{161}$

104 In fact, even the modern contracts doctrine of damage recovery "insist[s] only on 'reasonable certainty' rather than 'certainty' itself." E. FARNSWORTH \& W. YOUNG, supra note 153, at 634 (quoting Restatement (SECOND) of Contracts $§ 352$ (1979)).

105 See NLRB v. Sure-Tan, 672 F.2d at 604 ("It would be anomalous to encourage the honest toil of illegal aliens, accepting it with the understanding that these workers had the rights of employees under the Act, but then, when violations occur, to deny them such rights by refusing effective remedies.").

158 "[T]o limit the significance of discrimination merely to questions of monetary loss to workers would thwart the central purpose of the Act, directed as that is toward the achievement and maintenance of workers' self-organization." Phelps Dodge Corp. v. NLRB, 313 U.S. 177, 193 (1941).

187 The Sure-Tan discriminatees' unavailability for work after being arrested eliminated the possibility of a recovery under the conventional backpay approach. See NLRB v. Sure-Tan, 672 F.2d at 606 ("II]t may well be that the discriminatees will not have been lawfully available for employment in the United States . . . In that event [they] will receive no backpay.").

${ }_{158}$ As of September 1983, no visas were available for aliens classified as nonpreference aliens. See 8 U.S.G. § 1153(a) (1982). Even preference aliens who were neither the unmarried children of U.S. citizens nor exceptionally gifted scientists or artists faced a waiting period of at least 36 months. See Brief for the National Labor Relations Board at 49 n.47, Sure-Tan.

189 See J.P. Stevens \& Co. v. NLRB, 417 F.2d 533, 538 (5th Cir. 1969) ("In order to enable employees to enjoy these [section 7] rights, especially in lawful efforts to organize for collective representation, there are many instances in which the inescapably negative cease and desist order will not suffice."); Weiler, Promises to Keep: Securing Workers' Rights to Self-Organization Under the NLRA, 96 HARV. L. Rev. 1769,1788 n.67 (1983) ("I know of no one who claims that [a cease-and-desist order] by itself materially aids in the preservation of [the group right to a free choice about collective bargaining]."); Note, The Liability of Labor Relations Consultants for Advising Unfair Labor Practices, 97 HARv. L. Rev. 529, 531 (1983) ("The usual remedy for an unfair labor practice committed by an employer during an organizing campaign - a cease-and-desist order enjoining future violations-is viewed by many employers and consultants as a mere 'slap on the wrist." ") (footnote omitted).

The Sure-Tan majority, however, had confidence in the remedial effect of a ceaseand-desist order. See Sure-Tan, 104 S. Ct. at 2815 n.13.

${ }_{160}$ See generally J. ATLESON, supra note 51 (arguing that much of what appears incoherent in labor law can be understood once the hidden values and assumptions that underlie the doctrine are revealed).

161 Only the decision in NLRB v. MacKay Radio \& Tel. Co., 304 U.S. 333 (1938), presents a comparable abdication by the Court of its duty to interpret the 


\section{G. Sure-Tan's Undermining of the Public Policies of the NLRA}

While various principles of traditional contract law have been employed in labor cases, ${ }^{\mathbf{1 6 2}}$ the Court has also developed companion doctrines that served to check the development of an unbridled contractualist framework. ${ }^{163}$ One of the most significant of these is the so-called public rights doctrine. ${ }^{104}$

The language and the procedural design of the NLRA attest to both the premium that Congress placed on effective enforcement of the $\mathrm{Act}^{165}$ and the primacy of the public interest to be articulated and safeguarded by a specialized agency. ${ }^{168}$ The Board has exclusive jurisdiction to hear cases under the NLRA (appellate courts have limited reviewing authority and may issue legally binding enforcement orders), and it alone, through the General Counsel, has standing to enforce the Act. ${ }^{167}$ Moreover, "the Board appears to have absolute discretion

NLRA to promote the Act's central purposes. Despite section 13's instruction that "nothing in this subchapter . . . shall be construed so as to interfere with or impede or diminish in any way the right to strike," 29 U.S.C. $\$ 163$ (1982), the Court granted employers the right to hire permanent replacements for "economic" strikers. See MacKay, 304 U.S. at 345-46. The clear result of this grant is a chilling effect on the exercise of the right to strike, apparently in contradiction to the Act's express language.

162 See supra notes $142-47$ and accompanying text.

${ }_{163}$ See supra notes $148-49$ (discussing the Falk case).

164 See generally Klare, supra note 46, at 310-18 (discussing development of the public rights doctrine).

The tension between contractualism and anti-contractualism has often been played out in the form of the "public/private" debates in labor law: the frequently invoked distinction between the Act's call for state regulation of private economic activity and its simultaneous sanction of the free market and individualized private ordering. See generally Klare, The Public/Private Distinction in Labor Law, 130 U. PA. L. REv. 1358 (1982) (arguing, inter alia, that the public/private distinction is no more than a tool for reinforcing the status quo).

165 Because sanctions are so important to realizing the policies of the Act, Congress gave the exclusive power to enforce the NLRA to the government: "Congress did not see fit to leave prosecution of these usually small claims to scattered and often impecunious individual wage earners in a multiplicity of actions." Nathanson v. NLRB, 344 U.S. 25, 31 (1952) (Jackson, J., dissenting).

${ }_{168}$ See infra text accompanying note 173.

${ }^{167}$ Section 10(b) of the NLRA provides, in relevant part, that "[w]henever it is charged that any person has engaged in or is engaging in [an] unfair labor practice, the Board . . . shall have power to issue ... a complaint stating the charges in that respect, and containing a notice of hearing before the Board." 29 U.S.C. $\$ 160(\mathrm{~b})$ (1982). Section 3(b) provides, in relevant part, that "[t]here shall be a General Counsel of the Board . . . . He shall have final authority, on behalf of the Board, in respect of the investigation of charges and issuance of complaints under section $160, \ldots$ and in respect of the prosecution of such complaints before the Board . . ." 29 U.S.C. $\S 153$ (d) (1982).

Although private individuals may petition the Board to bring unfair labor practice charges against alleged violators, private actions to enforce the Act are not allowed. See Amalgamated Util. Workers v. Consolidated Edison Co., 309 U.S. 261, 265 (1940) ("The Board as a public agency acting in the public interest ... is chosen as the 
whether or not to bring an unfair labor practice proceeding."168 The salient fact is that the Board is a public agency "acting in the public interest"169 and enforcing public rights. ${ }^{170}$ The prohibitions and remedies of the NLRA, the Court has held, "are designed to aid in achieving the elimination of industrial conflict. They vindicate public, not private, rights."171

To effectuate the policies of the Act and to vindicate the public rights it created, Congress armed the Board with meaningful-though not unlimited-discretionary powers. Reducing these powers to a purely contractualist analysis of actual losses and compensable injuries, as did the Sure-Tan Court, is patently at odds with the procedural structure and purposes of the Act. Indeed, the Court long ago established that "[ $t]$ he Act does not create rights for individuals which must be vindicated according to a rigid scheme of remedies": ${ }^{172}$

To deny the Board power to neutralize discrimination ... . would confine the "policies of this Act" to the correction of private injuries. The Board was not devised for such a limited function. It is the agency of Congress for translating into concreteness the purpose of safeguarding and encouraging the right of self-organization. The Board ... does not exist for the "adjudication of private rights"; it "acts in a public capacity to give effect to the declared public policy of the Act . . . by encouraging collective bargaining."

instrument to assure protection from the described unfair conduct .... When the Board has made its order, the Board alone is authorized to take proceedings to enforce it."). The rules of standing have since been somewhat liberalized. See, e.g., UAW Local 283 v. Scofield, 382 U.S. 205, 208 (1965) (holding that both the charging and charged parties may intervene in an action appealing the Board's resolution of their dispute).

${ }^{188}$ Note, The Public Right Dogma in Labor Board Cases, 59 HaRv. L. Rev. 720,727 (1946). (1940).

${ }^{160}$ Amalgamated Util. Workers v. Consolidated Edison Co., 309 U.S. 261, 265

${ }_{170}$ The basic policy statements in section 1 of the Act emphasize that the Board is a public agency protecting the public interest. See 29 U.S.C. $\$ 151$ (1982); see also NLRB v. Fant Milling Co., 360 U.S. 301, 307-08 (1959) ("The Board was created not to adjudicate private controversies but to advance the public interest . . ..").

The interpretive framework that considers NLRA rights as "public rights" statutorily created and measured by the Board's expert discretion is admittedly far removed from the Court's early formulation of these rights as inherent in or deriving from a source of law more fundamental than a statute. See NLRB v. Jones \& Laughlin Steel Corp., 301 U.S. 1, 33 (1937) ("IT]he right of employees to self-organization and to select representatives of their own choosing for collective bargaining . . . is a fundamental right.") (emphasis added).

171 Virginia Elec. \& Power Co. v. NLRB, 319 U.S. 533, 543 (1943).

172 Phelps Dodge Corp. v. NLRB, 313 U.S. 177, 194 (1940).

${ }^{173}$ Id. at 192-93 (quoting National Licorice Co. v. NLRB, 309 U.S. 350, 362 
The Sure-Tan decision is sharply at odds with this vision of the Board and the remedies that the Board creates. Reading Sure-Tan, a stranger to American labor law might conclude that the NLRA is more analogous to a title from the Uniform Commercial Code than it is to a statute designed to further the public interest in workers' bargaining rights.

\section{TOWARDS AN EXPANDED INTERPRETATION OF THE BOARD's REMEdial AUTHORITY}

The Sure-Tan Court's fixation with compensating only perfectly measured losses and its relative lack of interest in the substantive, equitable outcome of the "transaction" produced a result that may be acceptable for a private contracts dispute but is wholly unacceptable for a dispute arising under the NLRA. Allowing an employer to discriminate against alien employees who organize and join unions, without providing an adequate remedy for the discriminatees, flouts "the rights of both alien and non-alien employees under the Act."174

The utter inadequacy and unprecedented nature of the Sure-Tan formulation of enforceable remedies calls for its rejection and signals the need to resurrect the core of the legal standard first articulated in Virginia Electric $\mathcal{E}^{\circ}$ Power Co. v. NLRB. ${ }^{175}$ Although precedent should not be overruled lightly, the Supreme Court has noted that "stare decisis is a principle of policy and not a mechanical formula of adherence to the latest decision, however recent and questionable, when such adherence involves collision with a prior doctrine more embracing in its scope, intrinsically sounder, and verified by experience."176 The escalation in number and increasing variety of charges of unfair labor practices $^{\mathbf{1 7 7}}$ require that Board remedies for unlawful discharges be even more creative and substantial than they have been in the past. Clearly there is an urgent need for a legal standard that recognizes both the importance of preserving the Board's remedial discretion and the necessity of judicial safeguards against abuses of that power.

A few safeguards against Board abuses of discretion are already in place and, contrary to the belief of the Sure-Tan Court, need not be

(1940)) (citation omitted).

174 NLRB v. Sure-Tan, 672 F.2d at 604.

178319 U.S. 533 (1943).

176 Helvering v. Hallock, 309 U.S. 106, 119 (1940).

177 See Weiler, Promises to Keep: Securing Workers' Rights to Self-Organization Under the NLRA, 96 HARv. L. REv. 1769, 1780 (1983) ("By 1980, . . . unfair labor practice charges against employers were up . . 200\% from 1965, and fully $750 \%$ from 1957. Worse, employees entitled to reinstatement in 1980 numbered 10,033, a $1000 \%$ increase from the low point in 1957.") (footnote omitted). 
expanded. One such safeguard is the prohibition of punitive awards. The Supreme Court has categorically denied enforcement to Board backpay awards deemed "punitive," even where such awards might arguably effectuate the policies of the Act. ${ }^{\mathbf{1 7 8}}$ The Court's decisions in this area have been, however, neither clear nor consistent; the Court itself has conceded on more than one occasion that the distinction between a proper remedy and an improper "punitive" sanction is a "bog of logomachy."179 There is no support, either in the language of the Act or in its legislative history, for the Court's rule against punitive orders. ${ }^{180}$ Nevertheless, allowing the Board complete discretion to issue backpay awards large enough to be considered fines might present significant constitutional problems. Due process rights, for instance, might be compromised by permitting the Board, through its informal procedures, to impose fines and other penalties for violations of the Act. ${ }^{181}$ In any event, fines or punitive damages, even if permissible, should be distinguished from backpay awards. The latter must bear a colorable relationship to the consequences of the loss of employment and are clearly authorized by the Act. ${ }^{182}$

The Sure-Tan standard of judicial review of Board remedies for unlawful discharge can be replaced with one in harmony with the purposes of the Act and previous Court decisions without abandoning the distinction between backpay orders and punitive damages. Because of the premium that Congress attached to ensuring the effectiveness of Board remedies, the primary criterion for assessing the propriety of Board remedies should be that they, as completely as possible in the circumstances of a particular case, effectuate the policies of the NLRA.

${ }^{128}$ See, e.g., Republic Steel Corp. v. NLRB, 311 U.S. 7, 11 (1940) (The Board lacks the "unlimited discretion to devise punitive measures, and thus to prescribe penalties or fines which [it] may think would effectuate the policies of the Act.").

179 NLRB v. Seven-Up Bottling Co., 344 U.S. 344, 348 (1953). The Sure-Tan Court quoted this language from Seven-Up in noting that it was unnecessary for it to determine if the minimum backpay ordered by the court of appeals was punitive. See Sure-Tan, 104 S. Ct. at 2816 n.14.

180 The doctrine against punitive remedies was established in Consolidated Edison Co. v. NLRB, 305 U.S. 197 (1938), a case challenging the invalidation of a contract, not the grant of a monetary award. The Court's opinion in Consolidated Edison was neither grounded in precedent nor based on the text or legislative history of the Act. See Note, supra note 108 , at 1680 ("The Court has never articulated a meaningful rationale for the doctrine .... ."). It has been argued that the Court could have construed the Act as authorizing punitive damages in some circumstances. See id. at 1679-83.

181 In contrast, the constitutionality of the Board's authority to order reinstatement and backpay was affirmed in Jones \& Laughlin Steel Corp. v. NLRB, 301 U.S. 1, 4849 (1937).

${ }_{182}$ See National Labor Relations (Wagner) Act $\S 10(c), 29$ U.S.C. $\S 160(c)$ (1982) ("T T]he Board shall . . . take such affirmative action including reinstatement of employees with or without back pay, as will effectuate the policies of this Act."). 
Especially important among these policies is the central goal of facilitating and protecting the self-organization of workers.

The argument has already been made that the statutory framework, the changing realities of industrial relations, and the undeniably political nature of the Board's task require that the Board have ample flexibility when applying the Act to particular cases. ${ }^{183}$ The same considerations require that Board decisions be upheld except in the rare instances in which an order is shown to be a "patent attempt" to achieve an end other than the Act's avowed goal of advancing the process of collective bargaining. ${ }^{184}$ As the Court, quoting the Virginia Electric test, ${ }^{185}$ declared in NLRB v. Seven-Up Bottling Co... ${ }^{186}$

In fashioning remedies to undo the effects of violations of the Act, the Board must draw on enlightenment.gained from experience. When the Board, "in the exercise of its informed discretion," makes an order of restoration by way of back pay, the order "should stand unless it can be shown that the order is a patent attempt to achieve ends other than those which can fairly be said to effectuate the policies of the Act." ${ }^{187}$

A court reviewing a Board remedy should adopt the principles recently put forth by the Court in Chevron, U.S.A. v. Natural Resources Defense Council. ${ }^{188}$ Under Chevron, if Congress has not registered its intent on the resolution of a specific statutory issue-as in the case of NLRA damage remedies-the question for the court is whether "the [agency's] view that [its interpretation] is appropriate in the context of [the] particular program is a reasonable one."189 In short, the Cheuron rule mandates that "a court may not substitute its own construction of a statutory provision for a reasonable interpretation made by the ... agency."180

Taken together, Virginia Electric and Cheoron require courts to uphold Board remedies that can reasonably (Chevron standard of review) be said to achieve ends that serve the goals of the NLRA (Virginia Electric standard for Board remedies). In contrast, the Sure-Tan

183 See supra text accompanying notes 46-65.

184 $C$ f. Virginia Elec. \& Power Co. v. NLRB, 319 U.S. 533, 540 (1943) (A Board order "should stand unless it can be shown that the order is a patent attempt to achieve ends other than those which can fairly be said to effectuate the policies of the Act.").

${ }^{185}$ See id.

188344 U.S. 344 (1953).

${ }^{187}$ Id. at 346-47 (quoting Virginia Electric, 319 U.S. at 540).

188104 S. Ct. 2778 (1984).

189 Id. at 2783 (emphasis added).

190 Id. at 2782 (footnote omitted). 
Court's standard of review was one of substituting its own judgment, and its standard for Board remedies was the requirement that they "expunge only the actual ... consequences of the unfair labor practices."191

The distinction between punitive fines and backpay awards may be preserved without adopting the Sure-Tan Court's contractualist formula, which approves of compensating only narrowly defined, demonstrable losses. That formulation belies the Court's own history of tolerating inexactitude and unacceptably subordinates the Board's mandate to advance the goals of the Act. A more comprehensive standard, one consistent with Virginia Electric, should be based on the principle that violators of the Act should derive no benefit from their wrongdoing. Thus, a backpay award should be upheld so long as the liability imposed on the employer is no greater than the costs that might reasonably have been incurred in the absence of an unfair labor practice.

This standard of acceptability would validate not only the SureTan backpay award, but also awards that do not deduct from the award the wages earned by the discriminatee in the period between discharge and reinstatement. Abandoning the requirement that interim wages be deducted from backpay awards is not "a patent attempt to achieve ends other than those which can fairly be said to effectuate the policies of the Act." ${ }^{\text {192 }}$ On the contrary, it furthers the policies of the NLRA. Because most unlawfully discharged employees have no choice but to obtain substitute employment, requiring the deduction of interim wages reduces backpay orders to "a minimal tariff far outweighed by [the employer's] benefit [derived from] halting incipient union activity."193

Nor would the proposed framework require applying the rule of mitigation. ${ }^{194}$ The only support given for the mitigation rule when it was announced was the pre-NLRA "maxim that mitigation doctrines serve[d] the beneficent purpose of 'promoting production and employment." "195 Even then only four of the seven Justices participating in the decision shared that belief. ${ }^{196}$ Abandoning the interim wage and

191 Sure-Tan, 104 S. Ct. at 2813-14.

192 Virginia Electric, 319 U.S. at 540.

193 Klare, supra note 46, at 334 n.273.

104 This rule of mitigation requires the Board to reduce a backpay award by the amount of wages "which the worker[ ] "failed without excuse to earn," Phelps Dodge Corp. v. NLRB, 313 U.S. 177, 197 (1940) (quoting Phelps Dodge Corp. v. NLRB, 113 F.2d 202, 206 (2d Cir.), modified, 313 U.S. 177 (1940)), after being denied or losing employment because of an unfair labor practice. See id. at 197-200.

${ }_{198}$ Klare, supra note 46, at 334 (quoting Phelps Dodge Corp. v. NLRB, 313 U.S. $177,200(1940)$ ).

${ }^{108}$ See id. at 334 n.273. 
mitigation deductions would depart from present practices. Such deductions, however, because they minimize backpay liability in periods of rising employment-when union activity is generally heightened-undermine the deterrent effect of the NLRA and so undermine the unionization process. ${ }^{197}$ Also, the courts have not yet developed a principled explanation of why a backpay award that perhaps makes a discriminatee "more than whole" but leaves the employer no worse off than it would have been in the absence of a violation should be deemed punitive. ${ }^{198}$

An expanded interpretation of section 10(c) would grant to the discriminatee all forms and any amount of compensation that would have been received from the employer if no violation had occurred, ${ }^{199}$ and would not deprive the Board of flexibility to respond creatively to the equitable demands of a given situation. For example, in Sure-Tan a finding that the discriminatees would have remained employed at the leather processing company for an additional six months without detection by the INS was reasonable. In another case, the Board might reasonably conclude that unlawful discharges retarded or altogether destroyed the process of collective bargaining. In such a case, effectuating the Act's policies would require that the backpay award include a wage increase if an increase would have been secured by the union absent a violation of the Act. Area standards or wage increases won by the union in comparable plants owned by the same employer could provide a reasonable point of reference. ${ }^{200}$ Because of the public interest in the Board carrying out its special role of vigorous enforcement of the Act,

197 See id.

${ }^{198} C$. Note, supra note 108 , at 1680 ("A review of the cases applying the rule against punitive orders suggests that the courts have applied the 'punitive' label in conclusory fashion to Board orders that seemed objectionable.") (footnote omitted).

189 Because losses caused by emotional distress, the costs of seeking substitute employment, and foregone opportunities, for example, would not be compensated under the proposed standard, it preserves the distinction between backpay and full compensatory damages that make the discriminatee whole. The latter may or may not be beyond the remedial scope of the Board. See generally id. at 1683-95 (arguing that, in certain situations, compensatory damages would "effectuate the policies of the Act" and should be permitted).

${ }^{200}$ Such an order would fall outside the ban developed in H.K. Porter Co. v. NLRB, 397 U.S. 99 (1969), on remedies imposing contract terms on the parties. A backpay award would have no prospective application; the wage increase incorporated in it would not outlast the date of offered reinstatement. It would not become a term of the contract as yet to be negotiated. If, upon the settlement of a collective bargaining agreement, the wage increase included in the backpay award turns out to be excessive, the employer could seek judicial review and modification of the order. $C f$. NLRB v. Otis Hosp., 545 F.2d 252, 257 (1st Cir. 1976) (allowing the Board to reconstruct the wage increase that the employer intended to give and to include this in the backpay award). 
an employer that challenges a backpay award should carry the burden of demonstrating that the award crosses the line separating the punitive from the remedial. This proposed standard would vindicate the policies of the NLRA abandoned by the Sure-Tan decision while protecting the employer from arbitrary or punitive actions on the part of the Board.

\section{CoNCLUSION}

Contractualism's victory in Sure-Tan over the clear purposes of the NLRA is doctrinally and politically significant. The decision runs strictly against a crucial current in labor law concerned primarily with preserving the substantive goals of the Act: ${ }^{201}$ the progress of collective bargaining and the protection of employees' rights to engage freely in concerted activities to improve the conditions of employment. At bottom, the decision represents the pre-NLRA view that the relationship between labor and management is not a political and social relationship that society as a whole, through its institutions of government and policymaking, has a vital stake in directing toward politically defined substantive ends. The contractualist view enshrined in Sure-Tan conceives of the labor-capital relationship as a commodity-exchange relationship to be governed by inbred notions and categories of traditional contract law. The decision severely limits the Board's ability to exercise its essentially political judgment on how best to advance the objectives of the Act. Whether or not a remedy is "just" after Sure-Tan is beyond political debate or solution; justice is measurable only in terms of actual losses and compensable injuries. The policy inclinations of individual Board appointees are irrelevant because Sure-Tan transforms the correction of section $8(\mathrm{a})(3)$ violations into a simple matter of addition and subtraction.

The Sure-Tan ruling also undermines, again contrary to the Act's clear declaration, the right of undocumented alien employees to band with each other and with other employees to participate in the control of the production process. The sanctions permissible under Sure-Tan are surely outweighed by the benefits an employer can expect to derive from stifling incipient unionism. The capacity of undocumented workers to engage in union activities should not be underestimated. Despite their precarious legal status and lack of social support mechanisms, undocumented alien workers have recorded a long history of labor militancy, especially in such cities as San Antonio, Los Angeles, and Chicago. ${ }^{202}$ With an estimated 3.5 million undocumented aliens already

${ }^{201}$ See, e.g., NLRB v. Falk Corp., 308 U.S. 453 (1939).

202 See D. Magiel, Al norte del Rio Bravo (1981). 
residing in the United States, and another 500,000 estimated to be entering the country each year, ${ }^{203}$ this sizable working population must be accounted for in state and federal labor laws and be taken seriously by organized labor. ${ }^{204}$ Without the protections eviscerated by the Court in Sure-Tan, the undocumented alien will be effectively denied the chance to participate in a collective process that inures ultimately to the benefit of all workers.

${ }^{203}$ See Schuck, The Transformation of Immigration Law, 84 CoLUM. L. REV. 1, 42 (1984).

206 Hotel \& Restaurant Employees Union, Local 25 v. Smith, 563 F. Supp. 157 (D.D.C. 1983), offers a recent, encouraging sign that at least some groups within organized labor are taking a progressive stand on the legal issues presented by the growing immigrant population. In Local 25, a union local challenged the Attorney General's decision to deny extended voluntary departure status to Salvadorans. Such status would permit the Salvadorans to avoid a return to their ravaged country and entitle them to remain in the United States while applying for authorization to work. See THE ImMigRation PROJECT OF THE NATIONAL LAWYER's Guild, supra note 8 , at $\S \S 4-$ 54.7 to -54.10 . 